\title{
ВЗАИМОДЕЙСТВИЕ БАЗИДИОМИЦЕТОВ С ПЕРЕМЕННО-ВАЛЕНТНЫМИ ЭЛЕМЕНТАМИ В СОСТАВЕ АСПАРТАТОВ БИОГЕННЫХ МЕТАЛЛОВ(II)
}

\author{
О.М. ЦИВИЛЕВАํㅛ, А.Н. ШАТЕРНИКОВ ${ }^{1}$, В.В. ФАДЕЕВ 1 , Е.В. ЛЮБУНЬ ${ }^{1}$, \\ В.Г. АМЕЛИН ${ }^{2}$, С.П. ВОРОНИН ${ }^{3}$, А.П. ГУМЕНЮК ${ }^{3}$, В.Е. НИКИТИНА 1
}

Важное направление развития научных основ искусственного культивирования грибов оптимизация минерального питания и доставки металлов(II). Органическая форма микроэлементов обладает значительными преимуществами перед неорганическими прекурсорами. Конъюгация металлов(II) (в частности $\mathrm{Cu}, \mathrm{Mn}, \mathrm{Fe}, \mathrm{Zn}, \mathrm{Co}$ ) с эссенциальными аминокислотами представляется решением проблемы биодоступности благодаря химическим процессам комплексообразования. В представленном исследовании мы впервые обнаружили и охарактеризовали действие аспартатов переменновалентных металлов(II) на ростовые процессы, биохимический отклик погруженных культур, антибактериальную активность грибных препаратов и плодоношение базидиомицетов родов Ganoderma, Grifola, Laetiporus, Lentinula и Pleurotus. Цель нашей работы состояла в выявлении и сравнении особенностей действия аспартатов переменновалентных металлов(II) на физиолого-биохимические показатели базидиомицетов. В работе использовали культуры трутовика лакированного (Ganoderma lucidum 1315), грифолы зонтичной (Grifola umbellata 1622), трутовика серно-желтого (Laetiporus sulphureus 120707), пилолистника съедобного (шиитаке) (Lentinula edodes F-249), вешенки устричной (Pleurotus ostreatus 69, ВК1702 и НК352). Аспартаты $\mathrm{Cu}(\mathrm{II}), \mathrm{Mn}(\mathrm{II}), \mathrm{Fe}(\mathrm{II}), \mathrm{Zn}(\mathrm{II}), \mathrm{Co}(\mathrm{II})$ в концентрации $1 \times 10^{-4}$ моль/л входили в состав питательных сред на основе глюкозы или пшеничного отвара при выращивании мицелия методом погруженного культивирования. Еще одним вариантом добавки к питательной среде была аспарагиновая кислота (Asp) в концентрации $2 \times 10^{-4}$ моль/л. Рост грибов при глубинном культивировании характеризовали по накоплению сухой биомассы. Мицелий фильтровали через предварительно взвешенные на аналитических весах фильтры, высушивали до постоянной массы и вновь взвешивали. Сравнивали прирост биомассы (по сравнению с 3-часовыми образцами культуры) в контрольном (без добавок аспартатов - хелатов аспарагиновой кислоты) и опытных вариантах. Субстратом для выращивания плодовых тел вешенки устричной служила лузга подсолнечника. Антибактериальную активность продуктов из погруженных грибных культур, выращенных в присутствии хелатов, определяли в отношении фитопатогенных бактерий Micrococcus luteus B-109, Pectobacterium carotovorum subsp. carotovorum (штаммы 603 и MI), Pectobacterium atrosepticum 1043, Pseudomonas fluorescens EL-2.1, Xanthomonas campestris В-610, используя метод диффузии в aгар. Эффект добавок на состав пула вторичных метаболитов грибных культур оценивали методом высокоэффективной жидкостной хроматографии/времяпролетной масс-спектрометрии высокого разрешения. Количественную оценку содержания металла в биологических пробах грибного происхождения проводили методом атомно-абсорбционной спектроскопии. Характеристики развития плодовых тел вешенки устричной оценивали в лаборатории, а затем в условиях грибоводческого хозяйства. Установлено, что аминокислотные хелаты биогенных металлов(II) служат факторами интенсификации выращивания посевного мицелия и плодообразования макробазидиомицетов в лабораторных условиях. Показано существенное ростостимулирующее действие хелатов меди, марганца, цинка и в менышей степени железа на мицелий базидиомицетов в условиях погруженного культивирования, в особенности в отношении трутовика лакированного, грифолы зонтичной, трутовика серно-желтого. Отмечалось весьма слабое стимулирование или даже ингибирование роста $P$. ostreatus 69 в вариантах с добавками Cu(Asp)2, Mn(Asp)2, Zn(Asp)2. Acпарагиновая кислота демонстрировала ингибирующий эффект вне зависимости от таксономических характеристик базидиомицетов. При культивировании вешенки устричной в присутствии аспартатов биогенных металлов выявлены межштаммовые различия в отношении быстро- и медленнорастущих культур к экзогенному воздействию хелатов металлов. В вариантах опыта Сu(Asp)2 и Zn(Asp)2 преимуществом обладал штамм P. ostreatus BK1702. Хелат марганца оказывал наиболее выраженное положительное действие на быстрорастущий штамм P. ostreatus HK352. По данным физико-химических исследований, аспартаты металлов(II), особенно Mn(Asp)2, Сu(Asp)2, влияют на биосинтез 5-гидроксиметилфурфурола, дигидропирона (структурный аналог койевой кислоты), пара-гидроксифенилуксусной кислоты, антиоксидантные свойства которых важны для грибной культуры. Положительное действие сочетаний хелатных соединений $\mathrm{Mn}(\mathrm{II}), \mathrm{Cu}(\mathrm{II}), \mathrm{Fe}(\mathrm{II})$, Zn(II) на жизнедеятельность P. ostreatus может быть эффективно использовано как для развития 
научных основ минерального питания высших грибов, так и в практическом грибоводстве. Аспартаты биогенных металлов могут служить действующим началом биопрепаратов для промышленного культивирования грибов. Характеристики развития мицелия и плодовых тел вешенки устричной с использованием в эксперименте аспартатов позволили рекомендовать к практическому применению хелат марганца(II).

Ключевые слова: базидиомицеты, физиолого-биохимические характеристики, биометаллы, аминокислотные хелаты, аспартаты.

Интерес к изучению влияния микроэлементов на физиологические, культуральные, биохимические свойства съедобных и лекарственных высших грибов обусловлен, с одной стороны, широким практическим применением, с другой - уникальностью базидиомицетов как объектов микробиологических и биохимических исследований $(1,2)$. Культивирование ксилотрофных макромицетов по сути представляет собой биотехнологический процесс утилизации лигноцеллюлозных отходов, с достаточной эффективностью конверсируемых в пищу человека или высококачественные корма с высокой питательной ценностью и улучшенной биодоступностью $(3,4)$.

Значительные усилия по совершенствованию производства функциональных ингредиентов и натуральных питательных добавок направлены на получение микроорганизмов, биомасса которых обогащена биометаллами (5-7). Так, весьма результативным может быть обогащение грибных культур субстанциями, содержащими эссенциальные элементы (8). Поэтому важным направлением развития научных основ искусственного культивирования грибов становится оптимизация минерального питания и доставки металлов(II), таких как медь, марганец, железо, цинк, кобальт.

Органическая форма микроэлементов обладает значительными преимуществами перед неорганическими прекурсорами (9-11), кроме того, при использовании в виде неорганических солей металлы малодоступны для утилизации организмами (12-14). Конъюгация металлов(II) (в частности $\mathrm{Cu}, \mathrm{Mn}, \mathrm{Fe}, \mathrm{Zn}, \mathrm{Co}$ ) с эссенциальными аминокислотами представляется решением проблемы биодоступности $(15,16)$ благодаря химическим процессам комплексообразования.

При взаимодействии аминокислот с ионами металлов при молярном соотношении металл:аминокислота, равном 1:(1-3), посредством образования ковалентно-координационных связей формируются хелаты (17). Аминокислоты и продукты ферментативного разрушения белков (небольшие пептиды) служат идеальными лигандами, поскольку обладают как минимум двумя функциональными группами, необходимыми для образования кольцевой структуры с металлом (18). Ионы металлов связываются с карбоксильными группами, а в комплексах аспарагиновой кислоты некоторые ионы металлов способны образовывать хелатную связь с аминогруппами $(19,20)$. Поэтому для ряда металлокомплексов аспарагиновой кислоты константы устойчивости в основном определяются сродством ионов металлов к аминогруппе (21), что приводит к избирательному связыванию ионов металлов и их переносу в комплексе с аспартатом $(22,23)$. Благодаря металл-координированному состоянию микроэлементов наблюдается повышение усвоения минеральных веществ организмом (24). Биоконъюгация металлов с аминокислотами - ценное средство функционализации природных белков и пептидов $(25,26)$.

Ранее нами была изучена биологическая активность грибных субстанций при включении в состав питательной среды биометаллов(II) в виде неорганических солей (27). В случае, когда экзогенным источником 
микроэлементов в глубинных культурах служили минеральные соли биометаллов, получить положительный биологический эффект не удавалось. Системные исследования по оптимизации минерального питания культивируемых грибов с применением аспартатов биогенных металлов ранее не проводились.

В представленной работе мы впервые обнаружили и охарактеризовали действие аспартатов переменновалентных металлов(II) на ростовые процессы, биохимический отклик погруженных культур, антибактериальную активность грибных препаратов и плодоношение базидиомицетов родов Ganoderma, Grifola, Laetiporus, Lentinula, Pleurotus.

Цель нашей работы состояла в выявлении и сравнении особенностей действия аспартатов переменно-валентных металлов(II) на физиолого-биохимические показатели базидиомицетов.

Методика. В работе использовали культуры трутовика лакированного (Ganoderma lucidum 1315), грифолы зонтичной (Grifola umbellata 1622), трутовика серно-желтого (Laetiporus sulphureus 120707), пилолистника съедобного (шиитаке) (Lentinula edodes F-249), вешенки устричной (Pleurotus ostreatus). Штаммы P. ostreatus BK1702 и НК352 - из коллекции базидиомицетов Института биохимии и физиологии растений и микроорганизмов РАН (ИБФРМ РАН), P. ostreatus 69 предоставлен Институтом микробиологии НАН Беларуси. Культуры грибов поддерживали на сусло-агаре (4 град. по Баллингу) при $4{ }^{\circ} \mathrm{C}$, в темноте.

Бактериальные тест-системы для изучения антимикробной активности выбирали на основе Специализированной научной коллекции ИБФРМ РАН (World Federation for Culture Collection - WFCC, \#975, World Data Center of Microorganisms - WDCM, \#1021). Антибактериальную активность продуктов из погруженных грибных культур, выращенных в присутствии хелатов, определяли в отношении фитопатогенных бактерий Micrococcus luteus B-109, Pectobacterium carotovorum subsp. carotovorum (штаммы 603 и MI), Pectobacterium atrosepticum 1043, Pseudomonas fluorescens EL-2.1, Xanthomonas campestris B-610.

Для культивирования использовали глюкозо-аспарагиновую среду, в состав которой входили 9,0 г/л D-глюкозы (концентрация 300 мМ по углероду), 1,5 г/л L-аспарагина (концентрация 20 мМ по азоту), и среду с дрожжевым экстрактом, содержащую 10 г/л D-глюкозы и 1 г/л дрожжевого экстракта. Для приготовления плотных сред в питательные растворы добавляли 1,8-2,0 \% (масса/объем) агара.

Посевную жидкую культуру вешенки устричной получали на мучной среде, приготовленной на основе отвара пшеничной муки. К 20 г пшеничной муки высшего сорта добавляли 100 мл холодной воды, размешивали до однородного состояния, полученную взвесь тонкой струей вливали в 900 мл кипящей воды и кипятили в течение 2-3 мин. Автоклавировали при избыточном давлении 1 атм. Температура выращивания культур составляла $26^{\circ} \mathrm{C}$.

Бактерии Micrococcus luteus, Pectobacterium carotovorum subsp. carotovorum, Pectobacterium atrosepticum, Pseudomonas fluorescens выращивали на среде следующего состава: мясной экстракт $-10,0$, пептон $-10,0, \mathrm{NaCl}-$ 5,0 г/л. Среда для выращивания Xanthomonas campestris имела состав: глюкоза - 20,0, дрожжевой экстракт - 10,0, $\mathrm{CaCO}_{3}-20,0$ г/л. Концентрация Bacto® Agar («Difco Laboratories Inc., США) для плотных сред составляла 18 г/л, рН доводили до 7,2-7,4. Все культуры выращивали при $28{ }^{\circ} \mathrm{C}$. 
Входящие в состав питательных сред на основе глюкозы или пшеничного отвара аспартаты $\mathrm{Cu}(\mathrm{II}), \mathrm{Mn}(\mathrm{II}), \mathrm{Fe}(\mathrm{II}), \mathrm{Zn}(\mathrm{II}), \mathrm{Co}(\mathrm{II})$ имели общую формулу М(Asp)2, где Asp - аспарагиновая кислота, и использовались в концентрации $1 \times 10^{-4}$ моль/л в пересчете на металл в готовой среде. Еще одним вариантом добавки к питательной среде была аспарагиновая кислота в концентрации $2 \times 10^{-4}$ моль/л. Аспартаты представляли собой негигроскопичные сыпучие мелкодисперсные порошки сиреневого цвета для кобальта, синего - для меди, бежевого - для железа, слабо бежевого для марганца, белого - для цинка. Аспартаты металлов(II) были получены прямым взаимодействием сульфатов металлов со стехиометрическим количеством аспарагиновой кислоты (Asp) по механизму комплексообразования в условиях нейтральной среды с последующей сушкой методом термического распыления (28).

Для получения мицелиальной культуры при посеве в качестве инокулята использовали 14-суточные культуры G. lucidum, G. umbellata, L. sulphureus, L. edodes, P. ostreatus, выращенные на агаризованном пивном сусле (4 град. по Баллингу). Способ дозирования посевной культуры состоял в засеве жидких сред дисками сусло-агара диаметром 5 мм с культурой гриба, взятыми с помощью стерильного металлического инструмента (пробойника) из одной зоны растущего мицелия. При засеве жидких сред предварительно намеченные пробойником диски мицелия из чашки Петри переносили стерильным скальпелем в колбы с соответствующими средами, обычно из расчета 3 диска на 50 мл среды. При засеве агаризованных сред диски мицелия переносили в центр чашки Петри, один диск на каждую чашку. Засев мучной среды осуществляли мицелием, выращенным на чашке Петри с агаризованным пивным суслом в течение 7-10 сут.

Растворы органических и неорганических солей, используемых в качестве добавок к среде выращивания, готовили в 50 \% (объем/объем) водном этаноле в концентрированном виде, а затем вносили с помощью автоматической пипетки в каждую из колб с жидкой средой либо расплавленной агаризованной средой, достигшей при остывании после автоклавирования температуры $\sim 40{ }^{\circ} \mathrm{C}$, перед заполнением чашек Петри. При расчете результирующей концентрации катионов $\mathrm{M}^{2+}$ в питательных средах учитывали указанное разведение. Вариант без добавок аспартатов или аспарагиновой кислоты служил контролем, используемым для разных грибных культур, в том числе для штаммов вешенки.

Для получения плодовых тел P. ostreatus посевной мицелий производился по стандартной технологии на зерне твердой пшеницы (29). Зерно выдерживали в горячей $\left(90{ }^{\circ} \mathrm{C}\right)$ воде в течение 20 мин и автоклавировали 30 мин в емкостях объемом 500 мл при избыточном давлении (1 атм) дважды, с интервалом 24 ч. Инокулятом служили глубинные культуры, выращенные на мучной среде в присутствии и в отсутствие (контроль) аспартатов металлов, в возрасте 14 сут. Посевной мицелий на мучной среде также получали в присутствии двойных смесей аминокислотных хелатов посредством введения аспартатов попарно в состав готового стерильного пшеничного отвара. В процессе роста на 3-и, 5-е, 7-е, 9-е, 14-е сут зерновой субстрат встряхивали для равномерной колонизации и выявления загрязнения конкурирующей микрофлорой. Культивирование осуществляли при 24-26 ${ }^{\circ} \mathrm{C}$ в течение 2 нед.

Субстратом для выращивания плодовых тел служила лузга подсолнечника - наиболее доступный и потому активно используемый в про- 
мышленном грибоводстве России лигноцеллюлозный субстрат. Плодовые тела выращивали в лабораторных условиях по стандартной методике на пастеризованном субстрате. После 2 нед в темноте емкости с колонизированным субстратом выставляли во влажную камеру на свет. На 15-е сут после инокуляции у всех исследуемых штаммов появились примордии. Далее вели ежедневное наблюдение за ростом плодовых тел. Эффект аспартатов металлов(II) оценивали по интенсивности освоения лузги подсолнечника мицелием P. ostreatus, выращенным на зерновом субстрате после засева жидкой культурой, полученной в присутствии $\mathrm{M}(\mathrm{Asp}) 2$ и без добавки. Аспартаты металлов использовали также для обработки лигноцеллюлозного субстрата из лузги семян подсолнечника. Характеристики развития плодовых тел оценивали в лаборатории, а затем в условиях грибоводческого хозяйства.

При глубинном культивировании полученный мицелий фильтровали через предварительно взвешенные на аналитических весах фильтры, высушивали до постоянной массы и вновь взвешивали. Сопоставляли прирост биомассы (по сравнению с 3-часовыми образцами культуры) в контрольном (без добавок аспартатов или Asp) и опытных вариантах. Скорость роста базидиомицетов при глубинном культивировании определяли по накоплению сухой биомассы в единицу времени в зависимости от продолжительности выращивания. О действии экзогенных аспартатов или аспарагиновой кислоты на культуры судили по накоплению биомассы мицелия в жидкой среде, в присутствии и в отсутствие L-аспартатов или Asp.

Металлсодержащие биообразцы грибного происхождения получали, как описано для неорганических солей (27). Чувствительность фитопатогенов к биоагентам грибного происхождения определяли, используя метод диффузии в агар (способ цилиндрических лунок, «колодцев»). Результаты оценивали по радиусу зон задержки роста бактерий вокруг лунки, не учитывая диаметр самого цилиндра. В некоторых опытах зоны угнетения имели овальную форму. В таких случаях измеряли наибольший и наименьший радиус зоны и вычисляли среднюю величину, которая и принималась за показатель бактерицидной активности.

Количественную оценку содержания металла в биологических пробах проводили методом атомно-абсорбционной спектроскопии на спектрометре iCE 3000 C093500037 v1.30 («Thermo Fisher Scientific», США) в Центре коллективного пользования (ЦКП) научным оборудованием в области физико-химической биологии и нанобиотехнологии «Симбиоз» ИБФРМ РАН.

Для определения эффекта добавок изучаемых хелатов на состав пула вторичных метаболитов грибных культур проводили сравнение экстрактов из питательных сред культивирования в контроле и с добавкой $10^{-4}$ моль/л аспартата металла(II). Для анализа использовали жидкостный хроматограф UltiMate 3000 («Thermo Fisher Scientific», США) в сочетании с квадруполь-времяпролетным масс-спектрометрическим детектором maXis Impact, maXis 4G («Bruker Daltonics», Германия). Разделение проводили на колонке $\left(150 \times 2,1\right.$ мм) Acclaim $^{\mathrm{TM}} 120 \mathrm{C} 18$ (2,2 мкм) («Thermo Fisher Scientific», США) в режиме градиентного элюирования подвижной фазы.

Использовали подвижные фазы, состоящие из $0,1 \%$ муравьиной кислоты в воде с добавлением 5 мМ формиата аммония (А) и 0,1 \% муравьиной кислоты в ацетонитриле (Б). Градиентное элюирование проводили смесью растворов А и Б в следующем режиме: 0 мин - $98 \%$ А $+2 \%$ Б, 15 мин $-100 \%$ Б, 20 мин $-100 \%$ Б, 30 мин $-98 \%$ А $+2 \%$ Б. Скорость потока подвижной фазы $-0,3$ мл $\cdot$ мин $^{-1}$, оптимальная температура 
хроматографической колонки $-35{ }^{\circ} \mathrm{C}$, объем вводимой пробы -20 мкл. Использовали электрораспылительную ионизацию в устройстве ionBooster («Bruker Daltonics», Германия). Выбор оптимальных значений параметров описан ранее $(30,31)$.

Диапазон регистрируемых масс ионов составлял 200-500 Да. В качестве калибранта использовали формиат натрия $(10 \mathrm{mM})$ в водном растворе изопропанола $(1: 1)$. Калибровку проводили в автоматическом режиме при записи хроматограммы. Погрешность в определении масс ионов не превышала \pm 5 ppm $(n=3)$.

Идентификацию осуществляли с использованием программного продукта TargetAnalysis-1.3. («Bruker Daltonics», Германия), обработку хроматограмм по общему ионному току и хроматограмм извлеченных масс ионов - с помощью DataAnalysis-4.1 («Bruker Daltonics», Германия), составление картины изотопного распределения аналитов - с применением IsotopePattern («Bruker Daltonics», Германия).

Полученные результаты обрабатывали статистически с использованием пакета программ Microsoft Excel. Приведены средние арифметические значения $(M)$ и стандартные отклонения $( \pm \mathrm{SD})$. Значения параметрического $t$-критерия Стьюдента находили для $95 \%$ уровня значимости.

Результаты. Аминокислотные хелаты биогенных металлов, в частности аспартатов, позволяют использовать микроэлементы в биодоступной органической форме при искусственном культивировании грибов. В качестве вещества, образующего соединение с металлами, применяется аспарагиновая кислота, при этом мольное соотношение аспарагиновая кислота:металл составляет 2:1.

В отличие от изученного ранее варианта с включением в состав питательной среды биометаллов(II) в виде неорганических солей (27), в настоящей работе уже на начальных этапах был выявлен высокий потенциал аспартатов, обладающих малотоксичностью и биологической активностью (28), для эффективного получения мицелиальной биомассы и плодоношения в лабораторных условиях. Концентрация микроэлементов составляла $1 \times 10^{-4}$ моль/л.

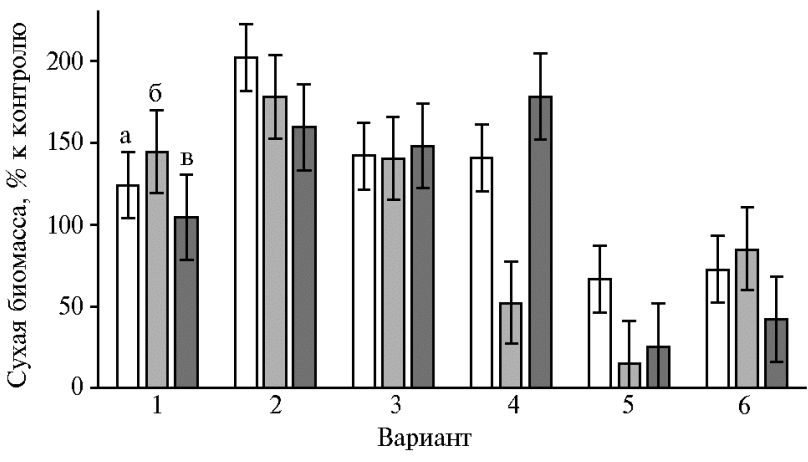

Рис. 1. Накопление биомассы глубинными культурами Ganoderma lucidum 1315 (a), Grifola umbellata 1622 (б) и Laetiporus sulphureus 120707 (в) через 21 сут культивирования на среде с глюкозой, дрожжевым экстрактом и добавками: 1 $\mathrm{Cu}($ Asp)2, $2-\mathrm{Mn}($ Asp)2, $3-\mathrm{Fe}($ Asp)2, $4-\mathrm{Zn}($ Asp)2, $5-$ $\mathrm{Co}($ Asp)2, $6-$ Asp $(M \pm \mathrm{SD})$.

В условиях погруженного культивирования большинство использованных добавок проявили существенное ростостимулирующее действие, в особенности в отношении Ganoderma lucidum 1315, Grifola umbellata 1622, Laetiporus sulphureus 120707 (рис. 1). Величина сухой биомассы достоверно превышала соответствующие значения в контрольных опытах без аспартатов $(\mathrm{p}<0,05)$.

Роль катионов металлов в стимуляции роста базидиомицетов можно объяснить способностью связывать и стабилизировать молекулы важных для ростовых процес- 
сов мицелия соединений с разнообразной химической структурой, размерными и зарядовыми характеристиками, растворимостью, липофильными свойствами, реакционной способностью. Определенную роль играет распределение зарядов. Отрицательный заряд поверхности мицелия, способствующий комплексообразованию в процессе взаимодействий металллиганд, обеспечивается как хитином, компонентом грибной клеточной стенки (32), так и присутствием карбоксильной, аминной, тиольной, амидной, иминной, тиоэфирной, фосфатной функциональных групп (33). В этом случае происходит не просто химическая реакция между металлсодержащими соединениями и поверхностью мицелия, в которой биомасса пассивно связывает ионы металлов по известным физико-химическим механизмам. Процесс взаимодействия культур с аспартатами - метаболически зависимый, что, несомненно, вносит вклад в разнообразие ответных реакций разных видов грибов (см. рис. 1) для одного и того же соединения металла.

При этом в опытах было отмечено весьма слабое стимулирование или даже ингибирование роста $P$. ostreatus 69 в вариантах с добавками органических солей $\mathrm{Cu}(\mathrm{Asp}) 2, \mathrm{Mn}(\mathrm{Asp})_{2}, \mathrm{Zn}(\mathrm{Asp}) 2$, которые оказывали значительный положительный эффект на рост других грибных культур (рис. 2).

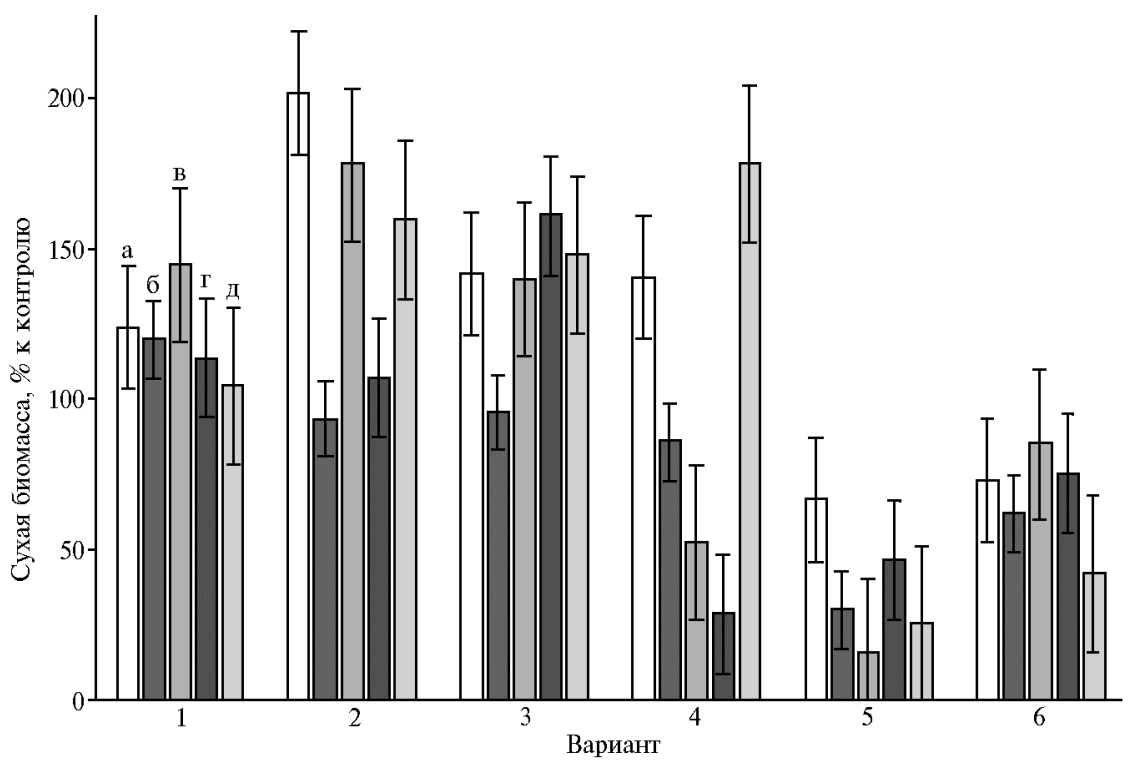

Рис. 2. Накопление биомассы глубинными культурами Ganoderma lucidum 1315 (a), Lentinula edodes F-249 (б), Grifola umbellata 1622 (в), Pleurotus ostreatus 69 (г) и Laetiporus sulphureus 120707 (д) через 21 сут культивирования на среде с глюкозой, дрожжевым экстрактом и добавками: 1 - $\mathrm{Cu}(\mathrm{Asp}) 2,2-\mathrm{Mn}($ Asp)2, $3-\mathrm{Fe}($ Asp)2, $4-\mathrm{Zn}(\mathrm{Asp}) 2,5-\mathrm{Co}(\mathrm{Asp}) 2,6-$ Asp $(M \pm \mathrm{SD})$.

Выраженная зависимость от таксономических характеристик базидиомицетов при их искусственном культивировании с неорганическими солями металлов имеет подтверждение в литературе. На примере меди и цинка была показана видоспецифичность эффектов металлов в отношении десятков культур съедобных грибов разного систематического положения $(6,34)$. При погруженном культивировании 11 культур штаммов ксилотрофов рода Trametes в присутствии солей меди, железа, марганца выявлены существенные различия в отношении активности лигнин-модифицирующих ферментов (35). Сульфаты $\mathrm{Cu}(\mathrm{II})$, Fe(II) и $\mathrm{Zn}(\mathrm{II})$ оказывали неодинаковое влияние на выход биомассы и метаболитов полисахаридной 
природы у гриба Antrodia cinnamomea (36).

Возникла задача подбора штамма $P$. ostreatus для более эффективного использования аминокислотных хелатов при получении посевного мицелия и плодовых тел этого гриба.

P. ostreatus имеет важное значение для искусственного культивирования прежде всего благодаря высокой продуктивности, ценным пищевым свойствам, содержанию значительного количества белка $(37,38)$, а также возможности использования для выращивания этих грибов субстратов, малопригодных для каких-либо других целей (непищевых отходов сельского хозяйства и промышленности) (39-41). Актуальные исследования роста $P$. ostreatus на жидких средах направлены на разработку технологии погруженного культивирования мицелия с целью получения биомассы кормового и пищевого назначения, разнообразных физиологически активных препаратов $(42,43)$ и биотехнологически ценных продуктов (4446). Погруженное культивирование известно как быстрый и эффективный метод производства посевного материала для грибоводства $(47,48)$.

Для выявления эффектов экзогенных аспартатов и аспарагиновой кислоты в отношении медленно- и быстрорастущих штаммов вешенки устричной оценивали накопление биомассы культурами штаммов P. ostreatus в жидкой среде в присутствии и в отсутствие L-аспартатов металлов(II) $(\mathrm{Cu}, \mathrm{Mn}, \mathrm{Fe}, \mathrm{Zn}, \mathrm{Co})$ и Asp. Исследовали штаммы вешенки устричной P. ostreatus 69, P. ostreatus BK1702 и P. ostreatus НK352. Рост P. ostreatus в глубинной культуре характеризовали по сухой массе мицелия при его выращивании на жидкой синтетической питательной среде с глюкозой и дрожжевым экстрактом. Биомасса глубинного мицелия P. ostreatus, культивируемого в отсутствие добавок, через 28 сут после засева составила $49,00 \pm 8,00,124,86 \pm 6,38$ и 244,7 $\pm 15,77$ мг/100 мл соответственно для штаммов 69, ВК1702 и НК352. Максимальное накопление биомассы в глубинной культуре было выявлено у P. ostreatus HK352.

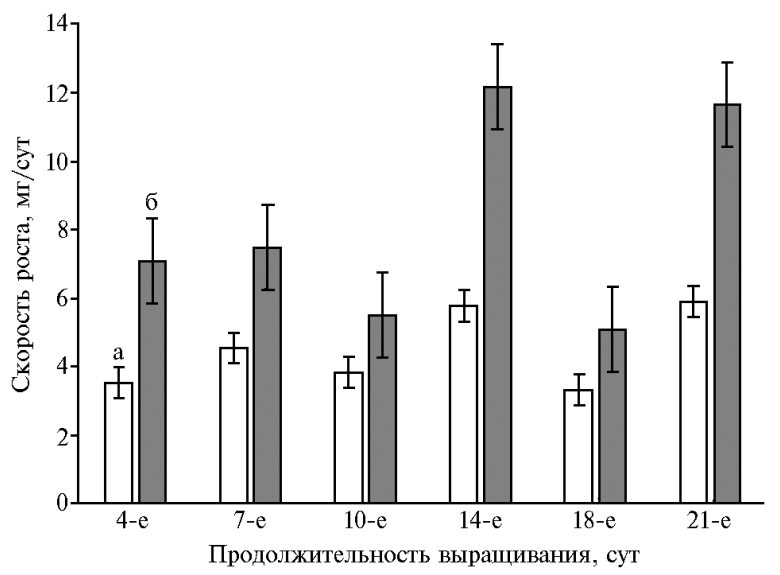

Рис. 3. Скорость роста погруженных культур Pleurotus ostreatus 69 (а) и HK352 (б) на среде с глюкозой и дрожжевым экстрактом в зависимости от продолжительности выращивания на жидкой среде $(M \pm \mathrm{SD})$.

Высокая скорость роста мицелия при искусственном культивировании связана с преимуществами перед контаминирующими видами, значительной конкурентоспособностью по отношению к посторонней микрофлоре, способностью утилизировать различные углеродсодержащие соединения, в том числе труднодоступные, из растительных отходов сельского хозяйства и лесоперерабатывающей промышленности. Из изученных нами штаммов вешенки устричной наиболее быстрорастущим оказался P. ostreatus HK352, медленнее других poc P. ostreatus 69 (рис. 3).

Оказалось, что ростовые характеристики вносят существенный вклад в чувствительность глубинных культур $P$. ostreatus к присутствию в питательной среде L-аспартатов металлов(II) (рис. 4). Аспарагиновая кислота 
демонстрировала слабый эффект, и межштаммовые различия в этом варианте опыта практически не проявлялись.

Присутствие органической соли кобальта в среде самого быстрорастущего штамма НК352 в наибольшей степени подавляло накопление биомассы (см. рис. 4). Под влиянием экзогенных Mn(Asp)2 и $\mathrm{Fe}(\mathrm{Asp})_{2}$ изменения этого показателя имели ту же или обратную направленность относительно показателей штаммов в контроле. Чувствительность медленнои быстрорастущих штаммов вешенки устричной к $\mathrm{Cu}(\mathrm{Asp})_{2}$ и $\mathrm{Zn}(\mathrm{Asp})_{2}$ оказалась неодинаковой. В указанных вариантах опыта преимуществом обладал P. ostreatus ВK1702 (см. рис. 4). Эти культуральные свойства следует учитывать при отборе штаммов для искусственного выращивания.

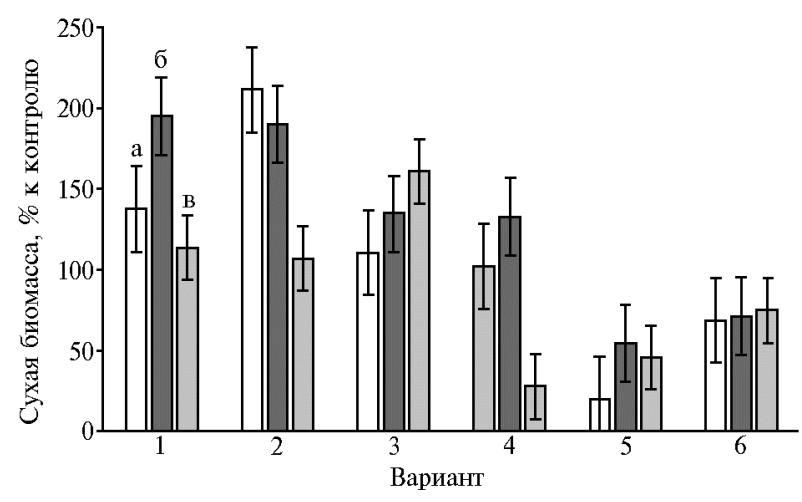

Рис. 4. Накопление биомассы глубинными культурами Pleurotus ostreatus HK352 (а), BK1702 (б) и 69 (в) через 21 сут на среде с глюкозой, дрожжевым экстрактом и добавками: $1-\mathrm{Cu}($ Asp)2, $2-\mathrm{Mn}($ Asp)2, $3-\mathrm{Fe}($ Asp)2, $4-\mathrm{Zn}($ Asp)2, $5-\mathrm{Co}(\mathrm{Asp}) 2,6-\mathrm{Asp}(\mathrm{M} \pm \mathrm{SD})$.

Микроэлементы в физиологических концентрациях могут быть частью активного сайта или действовать как активные модуляторы ферментов грибов (49). Показано, что активность лакказы, эндо$1,4-\beta$-глюканазы и $1,4-\beta-$ глюкозидазы P. ostreatus возрастает в присутствии цинка и меди (50). Цинк, медь и железо в культуральной среде способны оказывать сильное воздействие на состав клеточной стенки гриба, а также на содержание полифенолов и полисахаридов, которые участвуют в антиоксидантной, противоопухолевой, иммуномодулирующей и других видах биологической активности базидиомицетов $(51,52)$.

Однако следует учитывать, что металлы-микроэлементы необходимы для роста и развития грибных культур и проявления активности различных ферментов лишь при относительно низких концентрациях (6). Кобальт обладает достаточно высокой токсичностью для грибов, биоминерализация соединений Со в виде сульфата малоизучена даже для металлтолерантных видов (53), что объясняет более высокую чувствительность всех изученных нами штаммов в отношении $\operatorname{Co}(\mathrm{Asp}) 2$. Возможно, синергетические эффекты композиций грибных металлотионеинов, ответственных за связывание катионов металлов с разной токсичностью (54), приводят к усиленной биоаккумуляции кобальта и, следовательно, замеленному накоплению биомассы гриба.

Нами был охарактеризован биохимический отклик глубинных культур базидиомицетов на экзогенное воздействие изучаемых хелатов металлов. При анализе внеклеточного содержания металлов в составе хелатов методом атомно-абсорбционной спектроскопии оказалось, что в течение 2-недельного глубинного выращивания количество металла в культуральной жидкости снижалось в несколько раз по отношению к исходной концентрации в питательной среде (табл. 1). Аспартаты вовлекались в процессы роста и развития грибного мицелия.

Эффект добавок изучаемых хелатов металов(II) на состав пула вторичных метаболитов грибных культур оценивали методом высокоэффек- 
тивной жидкостной хроматографии/времяпролетной масс-спектрометрии высокого разрешения. Метод сочетает простую и быструю пробоподготовку с идентификацией и чувствительным определением низкомолекулярных вторичных метаболитов в биологических образцах.

1. Общая характеристика образцов и результаты детектирования металлов в фильтратах культуральной жидкости грибов при разном возрасте культуры $(M \pm \mathrm{SD})$

\begin{tabular}{|c|c|c|}
\hline \multirow{2}{*}{ Характеристика образца } & \multicolumn{2}{|c|}{ Концентрация $\mathrm{M}^{2+}$, мкг/мл } \\
\hline & 0 сут & 14 сут \\
\hline Lentinula edodes $\mathrm{Cu} 10^{-4}$ моль/л & 25,6 & $3,78 \pm 0,05$ \\
\hline Ganoderma applanatum $\mathrm{Cu} 10^{-4}$ моль/л & 25,6 & $1,49 \pm 0,06$ \\
\hline Ganoderma lucidum $\mathrm{Cu} 10^{-4}$ моль/л & 25,6 & $3,58 \pm 0,07$ \\
\hline Grifola umbellata $\mathrm{Cu} 10^{-4}$ моль/л & 25,6 & $2,54 \pm 0,02$ \\
\hline Pleurotus ostreatus $\mathrm{Cu} \mathrm{10-4} \mathrm{моль/л}$ & 25,6 & $3,83 \pm 0,01$ \\
\hline Laetiporus sulphureus $\mathrm{Cu} 10^{-4}$ моль/л & 25,6 & $2,51 \pm 0,03$ \\
\hline Lentinula edodes $\mathrm{Fe} 10^{-4}$ моль/л & 22,4 & $8,14 \pm 0,02$ \\
\hline Ganoderma applanatum $\mathrm{Fe} 10^{-4}$ моль/л & 22,4 & $2,90 \pm 0,01$ \\
\hline Ganoderma lucidum $\mathrm{Fe} 10^{-4}$ моль/л & 22,4 & $2,50 \pm 0,02$ \\
\hline Grifola umbellata $\mathrm{Fe} 10^{-4}$ моль/л & 22,4 & $3,44 \pm 0,01$ \\
\hline Pleurotus ostreatus $\mathrm{Fe} 10^{-4}$ моль/л & 22,4 & $3,61 \pm 0,01$ \\
\hline Laetiporus sulphureus $\mathrm{Fe} 10^{-4}$ моль/л & 22,4 & $1,93 \pm 0,01$ \\
\hline Lentinula edodes $\mathrm{Mn} 10^{-4}$ моль/л & 22,0 & $7,45 \pm 0,07$ \\
\hline Ganoderma applanatum $\mathrm{Mn} 10^{-4}$ моль/л & 22,0 & $0,33 \pm 0,01$ \\
\hline Ganoderma lucidum Mn 10-4 моль/л & 22,0 & $4,30 \pm 0,01$ \\
\hline Grifola umbellata $\mathrm{Mn} 10^{-4}$ моль/л & 22,0 & $6,39 \pm 0,19$ \\
\hline Pleurotus ostreatus $\mathrm{Mn} 10^{-4}$ моль/л & 22,0 & $6,98 \pm 0,02$ \\
\hline Laetiporus sulphureus Mn 10-4 моль/л & 22,0 & $6,26 \pm 0,02$ \\
\hline Lentinula edodes $\mathrm{Zn} 10^{-4}$ моль/л & 26,0 & $3,82 \pm 0,03$ \\
\hline Ganoderma applanatum $\mathrm{Zn} 10^{-4}$ моль/л & 26,0 & $3,12 \pm 0,01$ \\
\hline Ganoderma lucidum $\mathrm{Zn} 10^{-4}$ моль/л & 26,0 & $4,04 \pm 0,02$ \\
\hline Grifola umbellata $\mathrm{Zn} 10^{-4}$ моль/л & 26,0 & $3,35 \pm 0,01$ \\
\hline Pleurotus ostreatus medium $1 \mathrm{Zn} 10^{-4}$ моль/л & 26,0 & $2,66 \pm 0,07$ \\
\hline Laetiporus sulphureus $\mathrm{Zn} 10^{-4}$ моль/л & 26,0 & $2,95 \pm 0,01$ \\
\hline Lentinula edodes Co $10^{-4}$ моль/л & 23,6 & $8,48 \pm 0,01$ \\
\hline Ganoderma applanatum Со $10^{-4}$ моль/л & 23,6 & $5,17 \pm 0,01$ \\
\hline Ganoderma lucidum Сo $10^{-4}$ моль/л & 23,6 & $7,86 \pm 0,01$ \\
\hline Grifola umbellata Co $10^{-4}$ моль/л & 23,6 & $5,56 \pm 0,03$ \\
\hline Pleurotus ostreatus Co 10-4 моль/л & 23,6 & $8,89 \pm 0,01$ \\
\hline Laetiporus sulphureus Co $10^{-4}$ моль/л & 23,6 & $7,87 \pm 0,03$ \\
\hline
\end{tabular}

Экстракт из питательной среды с добавкой $10^{-4}$ моль/л аспартата металла(II) сравнивали с контролем (табл. 2). Согласно полученным данным, введение аспартатов некоторых металлов(II) в среду культивирования увеличивало продукцию 5-гидроксиметил-2-фуральдегида и дигидропирона (см. табл. 2) в грибной культуре. Ранее мы достаточно подробно обсуждали данные о повышенном содержании этих веществ в результате экзогенного действия некоторых соединений $(55,56)$. Так, среда глубинного культивирования базидиомицета Lentinula edodes в присутствии 1,5дифенил-3-селенпентандиона- $1,5 \mathrm{C}_{6} \mathrm{H}_{5} \mathrm{COCH}_{2} \mathrm{SeCH}_{2} \mathrm{COC}_{6} \mathrm{H}_{5}$ (диацетофенонилселенид, бис(бензоилметил)селенид, препарат ДАФС-25) (57), который при определенных концентрациях приводит к увеличению скорости роста гриба и повышению активности его внеклеточных лектинов, а также служит антиоксидантом, содержит 2-гидроксиметилфуран, 5-гидроксиметил2-фуральдегид, 3,5-дигидрокси-2-метил-5,6-дигидропиран-4-он (55).

В присутствии переходных металлов $(\mathrm{Cu}, \mathrm{Mn}, \mathrm{Fe}, \mathrm{Co})(58)$ в виде аспартатов, по-видимому, и происходит конверсия углеводов в 5-гидроксиметилфурфурол (59) посредством каталитического гидролиза и дегидратации гексозосодержаших компонентов питательной среды, приводящих к образованию 5-гидроксиметил-2-фуральдегида. Последний ингибирует фермент тирозиназу, ответственную за синтез грибного пигмента меланина, то есть служит ингибитором меланиногенеза (60). Нельзя не упомянуть, что 
в настоящее время признана значимость инновационного пути химической утилизации гексозосодержащего сырья, приводящего к образованию 5-гидроксиметил-2-фуральдегида - многообещающего полупродукта для химической промышленности (производства пищевых добавок, фармацевтических препаратов, полимерных материалов, добавок к моторным маслам и предшественников биотоплив) $(55,59,60)$.

2. Основные характеристики внеклеточных соединений, определяемые методом масс-спектрометрии высокого разрешения положительных ионов $[\mathrm{M}+\mathrm{H}]^{+}$, в среде культивирования Lentinula edodes с добавкой $10^{-4}$ моль/л аспартата металла(II)

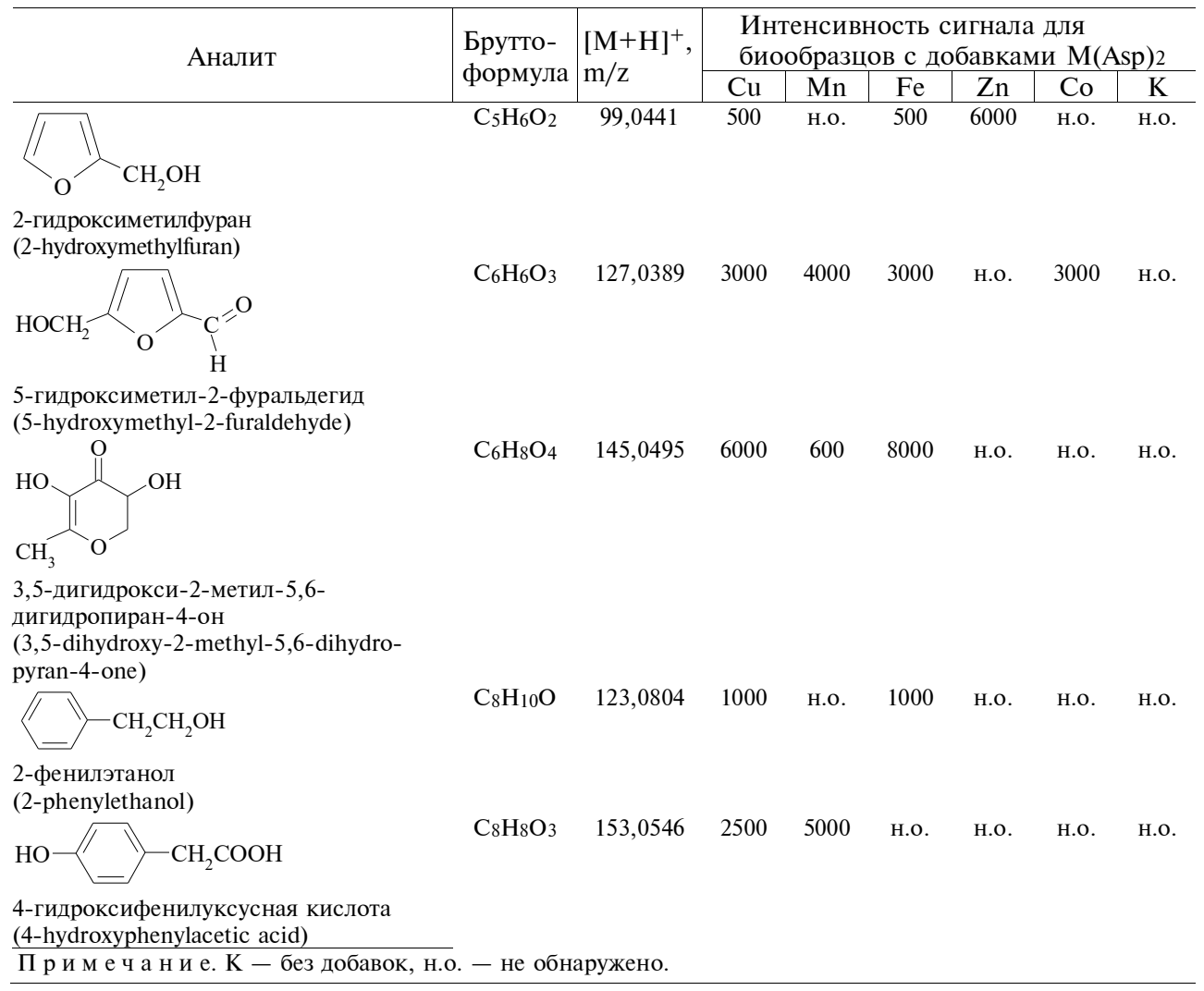

В культуральной жидкости в ряде случаев присутствовало соединение 3,5-дигидрокси-6-метил-2,3-дигидро-4Н-пиран-4-он (см. табл. 2). Отметим сходство структуры обнаруженного дигидропиранона и 5-гидрокси2-гидроксиметил-4Н-пиран-4-она, называемого также койевой кислотой. Койевая кислота - известный ингибитор меланиногенеза у грибов, который опосредован возрастанием активности тирозиназы и имеет место в условиях окислительного стресса $(61,62)$. Усиленный синтез этого вещества (в сравнении с культурой без добавок) говорит о повышенной антиоксидантной активности глубинного мицелия, выращенного в присутствии исследованных в работе аспартатов. Получено еще одно свидетельство усиления адаптационного потенциала грибной культуры, выращенной в присутствии аспартатов, в особенности хелатов меди, железа, марганца.

Как биохимический отклик грибных культур на присутствие в составе исходной питательной среды аспартатов в среде культивирования появлялись органические вещества с двойной связью, в том числе фенольной природы, не зарегистрированные в контроле. Максимальная вне- 
клеточная концентрация пара-гидроксифенилуксусной кислоты, судя по интенсивности аналитического сигнала (см. табл. 2), наблюдалась при интродукции $\mathrm{Mn}(\mathrm{Asp}) 2$. Эта фенольная кислота была детектирована в составе мицелия некоторых высших грибов: Chroogomphus rutilus (63), Suillus granulatus (64), Clitocybe nuda (65).

Считается, что антиоксидантная активность экстрактов грибов коррелирует с общим содержанием фенольных веществ (66). Именно 4гидроксифенилуксусная кислота в наибольшей степени по сравнению с другими экзогенными пара-гидрокси-замещенными фенольными соединениями (56) способствовала накоплению фенолов в мицелии.

Обнаруженное нами повышение количества соединений с антиоксидантными свойствами в присутствии ряда аспартатов в погруженных культурах базидиомицетов согласуется с данными, имеющимися в отношении других организмов. Известно, что антиоксидантные свойства соединений могут быть усилены при их использовании в различных синергетических композициях с другими антиоксидантами (67) и с веществами, которые сами по себе не проявляют указанной биологической активности $(68,69)$. Аспартаты $\mathrm{Cu}, \mathrm{Mn}, \mathrm{Zn}$ и $\mathrm{Mg}$ характеризовались ингибирующей активностью в отношении ксантин-оксидазы и НАДФН-оксидазы, снижая продукцию кислородных радикалов с участием этих ферментов. Наиболее активными ингибиторами развития окислительного стресса оказались аспартаты переходных металлов - меди $(70,71)$ и марганца (72). Эффект аспартатов цинка (73) и магния (74) можно связать с действием на скорость спонтанной дисмутации супероксид-иона. Разумно предположить, что $\mathrm{Cu}(\mathrm{Asp})_{2}, \mathrm{Mn}(\mathrm{Asp})_{2}$ и $\mathrm{Zn}(\mathrm{Asp})_{2}$ выступают в роли биомиметиков $\mathrm{Cu}-$, $\mathrm{Zn}$ - или Мn-зависимых супероксиддисмутаз. Антиоксидантные свойства аспартата цинка как эффективного ингибитора формирования наиболее реакционноспособных гидроксильных радикалов (75) продемонстрированы также в экспериментах с лабораторными животными (76).

Полученные результаты позволяют утверждать, что аминокислотные хелаты меди, железа и марганца могут влиять на продукцию соединений, важных для адаптации грибной культуры.

Для дополнительной характеристики биохимического отклика базидиомицетов на хелаты металлов с аспарагиновой кислотой мы исследовали антибактериальную активность продуктов из погруженных грибных культур, выращенных в присутствии хелатов, в отношении фитопатогенных бактерий Micrococcus luteus, Pectobacterium carotovorum subsp. carotovorum (2 штамма), Pectobacterium atrosepticum, Pseudomonas fluorescens, Xanthomonas campestris. Из глубинных культур G. lucidum, G. umbellata, L. sulphureus, L. edodes, P. ostreatus выделяли суммарный пул внеклеточных метаболитов, содержавший в том числе продукты биотрансформации грибами интродуцированных органических комплексов металлов(II). Наличие бактерицидного эффекта исследуемых металлсодержащих биокомпозитов проверяли с использованием метода диффузии в агар по отношению к фитопатогенным бактериям как тест-культуре (рис. 5).

Обсуждаемое выше свойство кобальта(II) ингибировать рост микроорганизмов на первый взгляд не коррелирует с низкой бактерицидной активностью его биокомпозитов грибного происхождения. Лишь в $50 \%$ случаев Со-содержащие биообразцы проявляли хотя бы минимальную токсичность в отношении фитопатогенов, и лишь композиты из G. lucidum характеризовались шириной зоны ингибирования более 2 мм в опытах с ингибированием P. atrosepticum (рис. 5, А) и P. carotovorum MI (см. рис. 5, 
Б). Концентрация М(II) в потенциально антибактериальных образцах с кобальтом и с другими металлами была одинакова. Можно предположить, что продукция внеклеточных метаболитов, сниженная из-за замедленного прироста биомассы в присутствии аспартата кобальта, не вносит достаточного вклада в формирование Со-композитов. На наш взгляд, получение субстанций грибного происхождения при низком содержании внеклеточных метаболитов, способных проявлять противомикробный эффект, приводит к резко сниженной способности подавлять жизнеспособность изученных фитопатогенных бактерий. Дополнительное косвенное подтверждение важности химического окружения металла следует учитывать при использовании его соединений для борьбы с фитопатогенами.
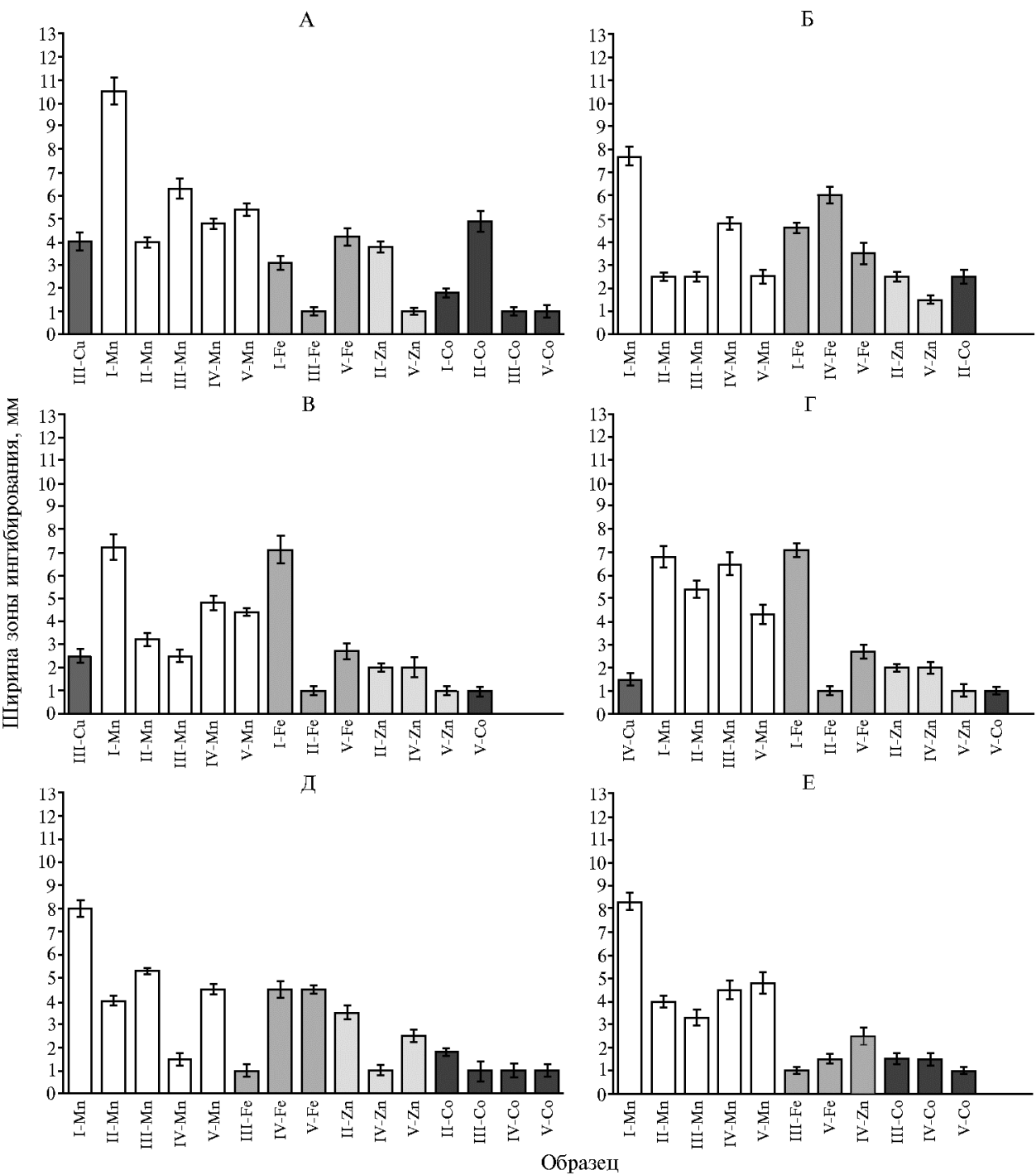

Рис. 5. Ингибирующая активность биокомпозитов, содержащих $\mathrm{Cu}, \mathrm{Mn}, \mathrm{Fe}, \mathrm{Zn}, \mathrm{Co}$, на основе Pleurotus ostreatus HK352 (I), Ganoderma lucidum 1315 (II), Lentinula edodes F-249 (III), Grifola umbellata 1622 (IV), Laetiporus sulphureus 120707 (V), в отношении бактериальных культур: А Pectobacterium atrosepticum 1043, Б - Pectobacterium carotovorum subsp. carotovorum MI, B Xanthomonas campestris B-610, Г - Pectobacterium carotovorum subsp. carotovorum 603, Д - Mi-

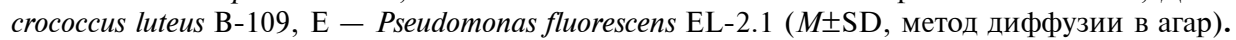

Аспартаты других металлов, проявляя ростостимулирующие свой- 
ства в отношении базидиомицетов (см. рис. 1), весьма существенно различались по действию металлсодержащих биосубстанций на бактериальные патогены растений. Практически не наблюдалось ингибирования бактериального роста в присутствии биокомпозитов меди. Только из культуральной жидкости Lentinula edodes удалось получить антибактериальный образец, характеризовавшийся заметной зоной ингибирования роста $P$. atrosepticum (см. рис. 5, А) и X. campestris (см. рис. 5, В). Биокомпозит из Grifola umbellata был малоэффективен (см. рис. 5, Г). Вероятно, индукция медьсодержащих литических ферментов в присутствии этого катиона, отмеченная у большого числа микроорганизмов $(44,46)$ и необходимая в том числе для освоения питательного субстрата бактериями, благоприятствует выживанию фитопатогенов. Этому же способствует и биопродукция бактериальных медь-редуктаз (32), катализирующих трансформацию металла в менее токсичные химические формы.

Считается, что марганец отвечает за индукцию марганец-пероксидазы у микроорганизмов, прежде всего высших грибов. Однако проведенные исследования (50) показали отрицательную корреляцию максимума Mn-пероксидазной активности с концентрацией экзогенного Mn. Было обнаружено, что эта ферментативная активность в присутствии Mn ниже, чем в его отсутствие. Возможно, с этим отчасти была связана наблюдаемая в нашем эксперименте высокая противомикробная активность грибных субстанций, содержащих марганец в биодоступной органической форме (см. рис. 5). При их действии на бактериальные тест-системы может снижаться указанная пероксидазная активность. Одновременно при стимулировании ионами $\mathrm{Mn}^{2+}$ активность лакказ (и лигнин-пероксидаз) может не обнаруживаться, как это происходит у микроорганизмов, имеющих различную таксономическую принадлежность и экологическую стратегию (77). Действительно, самые высокие количественные характеристики бактерицидного действия были обнаружены в варианте с Mn(Asp)2. Эффект этого хелата марганца как компонента среды выращивания погруженной культуры, используемой для изготовления потенциально бактерицидных образцов, оказался гораздо более выраженным, чем у $\mathrm{Zn}(\mathrm{Asp}) 2$ и особенно $\mathrm{Fe}(\mathrm{Asp}) 2$, и проявлялся в отношении всех тестируемых штаммов фитопатогенов (см. рис. 5). Единственное исключение - к действию марганец-содержащего ингибитора, полученного из Grifola umbellata, не были чувствительны бактерии Pectobacterium carotovorum subsp. carotovorum 603 (см. рис. 5, Г).

Абсолютный максимум величины зоны ингибирования в нашем эксперименте наблюдался при угнетении бактерий P. atrosepticum биоагентами на основе внеклеточных метаболитов P. ostreatus, изготовленными при введении в питательные среды $\mathrm{Mn}(\mathrm{Asp}) 2$ (см. рис. 5, А). На втором месте - этот же грибной продуцент органической части биокомпозита, содержащего Zn(II). Однако указанный Zn-содержащий биоагент действовал исключительно на фитопатоген P. carotovorum 603 (см. рис. 5, Г).

Другие $\mathrm{Zn}(\mathrm{II})$-композиты грибного происхождения проявляли умеренную бактерицидную активность и были эффективны менее чем в половине опытов с использованием $\mathrm{Zn}(\mathrm{Asp}) 2$. На основе внеклеточных метаболитов одного из базидиомицетов, Lentinula edodes, не удалось получить Znсодержащего антибактериального агента. То есть, наряду с селективным ингибитором роста $P$. carotovorum 603, все грибные металлсодержащие биообразцы, в которых величина зоны ингибирования бактериального ро- 
ста составляла не менее 8 мм, были получены с использованием Mn(Asp)2 (см. рис. 5 Д, Е).

Аспартат железа в составе биоагента в единичных случаях мало уступал по бактерицидному действию (см. рис. 5, В) или даже проявлял чуть большую эффективность (см. рис. 5, Г) в сравнении с $\mathrm{Mn}(\mathrm{Asp}) 2$, однако эти результаты были получены только с использованием P. ostreatus. Почти не действовали биокомпозиты железа грибного происхождения на бактерии Ps. fluorescence (см. рис. 5, Е).

Почвенные микроорганизмы, включая ряд представителей родов Pseudomonas, Bacillus, Rhizobium, Azotobacter, могут быть использованы для увеличения фитодоступности минеральных веществ, оздоровления растений, биоконтроля $(24,32)$. В лабораторных условиях такие эксперименты проводились успешно, однако практическое распространение метода бактериального биоконтроля требует всестороннего учета своеобразия и уникальности стратегии защиты растений в зависимости от культивара, химических свойств почвы, внешней среды. Способность потенциально биоконтрольных препаратов конкурировать с резидентными ризобактериями при колонизации корней в условиях природных экосистем сильно варьирует и далеко не всегда предсказуема. Тем не менее вопрос о взаимодействии препаратов на основе предлагаемых нами биокомпозитов с препаратами на основе ризобактерий имеет важность. Тот факт, что в наших экспериментах бактерицидная активность против Pseudomonas fluorescens oказалась наименее выраженной (см. рис. 5), представляет интерес с точки зрения возможного решения проблемы отрицательного влияния биоконтрольных препаратов на резидентные ризобактерии. В частности, для этого могут использоваться препараты на основе биокомпозитов, к которым культура $P$. fluorescens толерантна, или совместимые с биокомпозитами культуры полезных ризобактерий. Кроме того, перспективны дальнейшие исследования по выявлению фунгицидных свойств металлсодержащих агентов грибного происхождения.
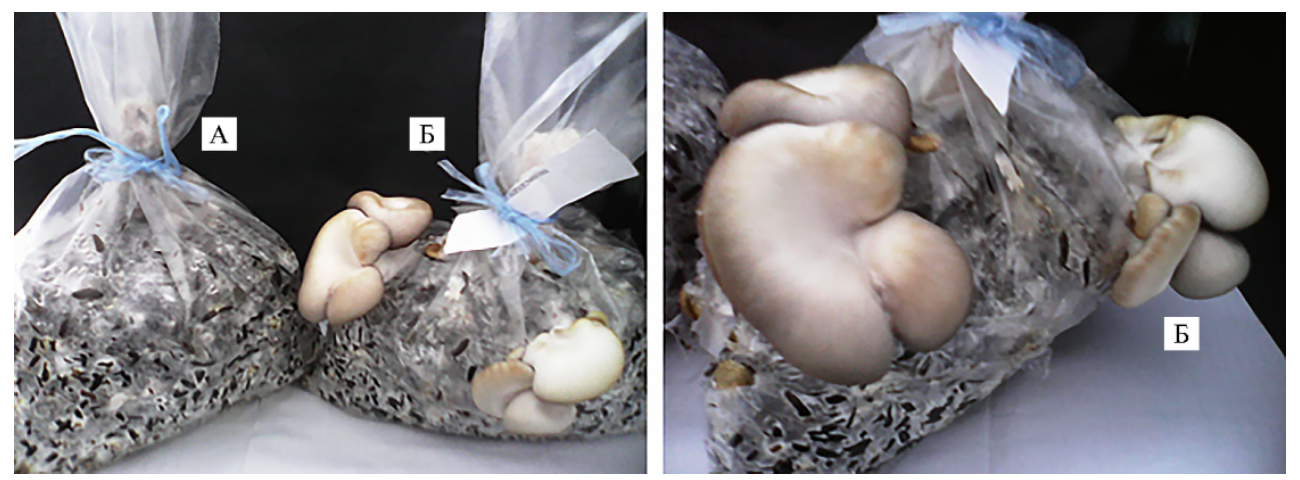

Рис. 6. Освоение лузги подсолнечника мицелием Pleurotus ostreatus НК352, выращенным на зерновом субстрате после засева жидкой культурой, полученной без добавок (А) и в присутствии $1,0 \times 10^{-4}$ моль/л Mn(Asp)2 (Б).

B наших опытах была оценена возможность использования L-acпартатов металлов(II) как действующего начала биопрепаратов комплексного действия (ростостимулирующего и адаптогенного) для промышленного культивирования $P$. ostreatus. Накопление биомассы погруженного мицелия штаммов $P$. ostreatus под влиянием экзогенного $\mathrm{Mn}(\mathrm{Asp}) 2$ (см. рис. 2) менялось в том же порядке, что и накопление биомассы культур штаммов в контроле, то есть можно сделать предположение 
о наиболее выраженном положительном действии хелата марганца на быстрорастущий штамм $P$. ostreatus HK352. Посевную жидкую культуру штамма получали на среде с отваром пшеничной муки, а также на среде с добавками каждого из аспартатов - Cu, Mn, Fe, Zn. Освоение зернового субстрата мицелием P. ostreatus при выращивании посевной жидкой культуры в присутствии перечисленных органических солей происходило интенсивнее, чем в контроле.

Мицелий, полученный на субстрате из зерна пшеницы, использовали в качестве посевного материала для выращивания плодовых тел на субстрате из лузги семян подсолнечника. Судя по интенсивности освоения этого лигноцеллюлозного субстрата мицелием P. ostreatus, выращенным в присутствии $\mathrm{Mn}(\mathrm{Asp}) 2$ (рис. 6), наиболее благоприятное действие на развитие плодовых тел вешенки оказывал хелат марганца(II).

В биотехнологическом плане представляет интерес учет и рациональное использование культуральных свойств штаммов при их отборе для искусственного выращивания вешенки устричной в присутствии микроэлементных добавок в форме аминокислотных хелатов. Ростовой показатель под влиянием экзогенного $\mathrm{Fe}(\mathrm{Asp}) 2$ (см. рис. 2) менялся в порядке, обратном ростовым показателям штаммов в контроле (см. рис. 2), то есть наибольшую толерантность к хелату железа, в том числе в его смешанных с другими аспартатами препаратах, следовало ожидать от медленнорастущего штамма P. ostreatus 69. В то же время характер изменения чувствительности $P$. ostreatus к Cu(Asp)2 и $\mathrm{Zn}(\mathrm{Asp})_{2}$ (см. рис. 2) показал явное преимущество штамма ВК1702 с умеренной скоростью роста.

Оценку воздействия смесей аспартатов на рост и развитие культур трех штаммов $P$. ostreatus проводили, основываясь на данных как о ростовых параметрах культур, так и о толерантности штаммов к экзогенному воздействию изучаемых хелатов металлов.

Аспартаты металлов использовали для введения в состав жидкой среды для получения мицелия, обработки зернового субстрата на следующем этапе получения посевного материала, обработки лигноцеллюлозного субстрата для получения плодовых тел $P$. ostreatus. Оказалось, что наибольшей эффективностью по накоплению биомассы погруженного мицелия, скорости освоения зернового субстрата, сокращению сроков до начала плодоношения и повышению его интенсивности обладали смешанные препараты аминокислотных хелатов марганца и цинка, меди и цинка.

На основании полученных результатов можно предложить некоторые принципы биотехнологической схемы использования органических солей металлов-микроэлементов в процессах выращивания мицелия вешенки устричной. Для наиболее быстрорастущих культур штаммов $P$. ostreatus целесообразно использовать сочетания аспартатов марганца и цинка в эквимолярном соотношении. Штаммы $P$. ostreatus с умеренной скоростью роста в погруженной культуре демонстрировали усиленное развитие мицелия на всех питательных средах при введении в их состав сочетания аспартатов меди и цинка в мольном соотношении 1:2. Обработка плотных субстратов, используемых для получения плодовых тел вешенки устричной, приводила у медленнорастущих штаммов P. ostreatus к положительным результатам при использовании аспартатов железа и цинка в мольном соотношении 1:2. Хелатные соединения биогенных металлов в вышеуказанных сочетаниях оказывали положительное влияние на жизнедеятельность $P$. ostreatus.

Таким образом, аминокислотные хелаты биогенных металлов(II) 
служат факторами интенсификации выращивания посевного мицелия и плодообразования макробазидиомицетов в лабораторных условиях. Показано существенное ростостимулирующее действие хелатов меди, марганца, цинка и в меньшей степени железа на мицелий базидиомицетов в условиях погруженного культивирования, в особенности в отношении трутовика лакированного, грифолы зонтичной, трутовика серно-желтого. Отмечалось весьма слабое стимулирование или даже ингибирование роста Pleurotus ostreatus 69 в вариантах с добавками Cu(Asp)2, Mn(Asp)2, Zn(Asp)2, которые оказывали значительный положительный эффект на рост других грибных культур. Аспарагиновая кислота демонстрировала ингибирующий эффект вне зависимости от таксономических характеристик базидиомицетов. При культивировании вешенки устричной в присутствии аспартатов биогенных металлов выявлены межштаммовые различия в отношении быстро- и медленнорастущих культур к экзогенному воздействию хелатов металлов. В вариантах опыта $\mathrm{Cu}(\mathrm{Asp}) 2$ и $\mathrm{Zn}(\mathrm{Asp}) 2$ преимуществом обладал штамм P. ostreatus ВK1702. Хелат марганца оказывал наиболее выраженное положительное действие на быстрорастущий штамм P. ostreatus HK352. По данным физико-химических исследований, аспартаты металлов(II), особенно $\mathrm{Mn}(\mathrm{Asp}) 2, \mathrm{Cu}(\mathrm{Asp}) 2$, влияют на биосинтез 5-гидроксиметилфурфурола, дигидропирона (структурный аналог койевой кислоты), пара-гидроксифенилуксусной кислоты, антиоксидантные свойства которых важны для проявления адаптационных свойств грибной культуры. Положительное действие сочетаний хелатных соединений $\mathrm{Mn}(\mathrm{II}), \mathrm{Cu}(\mathrm{II}), \mathrm{Fe}(\mathrm{II}), \mathrm{Zn}(\mathrm{II})$ на жизнедеятельность $P$. ostreatus может быть эффективно использовано как для развития научных основ минерального питания высших грибов, так и в практическом грибоводстве. Предложена биотехнологическая схема использования органических солей металлов-микроэлементов при выращивании мицелия вешенки устричной. Полученные данные свидетельствуют о высоком потенциале применения смесей аминокислотных хелатов металлов(II) в виде аспартатов для эффективного получения мицелиальной биомассы и плодоношения в лабораторных условиях. Аспартаты биогенных металлов могут служить действующим началом биопрепаратов для промышленного культивирования грибов. Характеристики развития мицелия и плодовых тел вешенки устричной с использованием в эксперименте аспартатов позволили рекомендовать к практическому применению хелат марганца(II).

Авторы выражают благодарность профессору А.Н. Панкратову (Институт химии Саратовского национального исследовательского государственного университета имени Н.Г. Чернышевского) за научно-организационное содействие.

\section{ЛИТЕРАТУРА}

1. Ogidi C.O., Oyetayo V.O., Akinyele B.J., De Carvalho C.A., Kasuya M.C.M. Food value and safety status of raw (unfermented) and fermented higher basidiomycetes, Lenzites quercina (L.) P. Karsten. Preventive Nutrition and Food Science, 2018, 23(3): 228-234 (doi: 10.3746/pnf.2018.23.3.228).

2. Rathore H., Prasad S., Kapri M., Tiwari A., Sharma S. Medicinal importance of mushroom mycelium: mechanisms and applications. Journal of Functional Foods, 2019, 56: 182-193 (doi: 10.1016/j.jff.2019.03.016).

3. Guo L.-Q., Lin J.-Y., Lin J.-F. Non-volatile components of several novel species of edible fungi in China. Food Chemistry, 2007, 100(2): 643-649 (doi: 10.1016/j.foodchem.2005.09.087).

4. Akyüz M., Kirbağ S. Effect of various agro-residues on nutritive value of Pleurotus eryngii (DC. ex Fr.) Quel. var. ferulae Lanzi. Journal of Agricultural Sciences, 2010, 16: 83-88.

5. Figlas D., Oddera M., Curvetto N. Bioaccumulation and bioavailability of copper and zinc on mineral-enriched mycelium of Grifola frondosa. Journal of Medicinal Food, 2010, 13(2): 469-475 
(doi: 10.1089/jmf.2008.0284).

6. Matute R.G., Serra A., Figlas D., Curvetto N. Copper and zinc bioaccumulation and bioavailability of Ganoderma lucidum. Journal of Medicinal Food, 2011, 14(10): 1273-1279 (doi: 10.1089/jmf.2010.0206).

7. Poursaeid N., Azadbakht A., Balali G.R. Improvement of zinc bioaccumulation and biomass yield in the mycelia and fruiting bodies of Pleurotus florida cultured on liquid media. Applied Biochemistry and Biotechnology, 2015, 175(7): 3387-3396 (doi: 10.1007/s12010-015-1510-9).

8. Liu J., Bao W., Jiang M., Zhang Y., Zhang X., Liu L. Chromium, selenium, and zinc multimineral enriched yeast supplementation ameliorates diabetes symptom in streptozocin-induced mice. Biological Trace Element Research, 2012, 146(2): 236-245 (doi: 10.1007/s12011-011-9248-x).

9. Zafar M.H., Fatima M. Efficiency comparison of organic and inorganic minerals in poultry nutrition: a review. PSM Veterinary Research, 2018, 3(2): 53-59.

10. Gharibzahedi S.M.T., Jafari S.M. The importance of minerals in human nutrition: bioavailability, food fortification, processing effects and nanoencapsulation. Trends in Food Science \& Technology, 2017, 62: 119-132 (doi: 10.1016/j.tifs.2017.02.017).

11. Egorova K.S., Ananikov V.P. Toxicity of metal compounds: knowledge and myths. Organometallics, 2017, 36(21): 4071-4090 (doi: 10.1021/acs.organomet.7b00605).

12. Tuhy Ł., Samoraj M., Michalak I., Chojnacka K. The application of biosorption for production of micronutrient fertilizers based on waste biomass. Applied Biochemistry and Biotechnology, 2014, 174(4): 1376-1392 (doi: 10.1007/s12010-014-1074-0).

13. Witkowska Z., Rusek P., Witek-Krowiak A., Chojnacka K., Tuhy Ł., Samoraj M. Production of dietary feed supplements enriched in microelements in a pilot plant biosorption system. International Journal of Environmental Science and Technology, 2016, 13(4): 1089-1098 (doi: 10.1007/s13762-016-0945-z).

14. Gins M., Gins V., Motyleva S., Kulikov I., Medvedev S., Kononkov P., Pivovarov V. Mineral composition of amaranth (Amaranthus L.) seeds of vegetable and grain usage by ARHIVBSP selection. Potravinarstvo Slovak Journal of Food Sciences, 2018, 12(1): 330-336 (doi: 10.5219/863).

15. Beshkenadze I., Chagelishvili A., Begheluri G., Zhorzholiani N., Gogaladze M., Urotadze S., Klarjeishvili N. New generation premixes for rabbit nutrition. Annals of Agrarian Science, 2016, 14(4): 288-291 (doi: 10.1016/j.aasci.2016.06.001).

16. De Marco M., Zoon M.V., Margetyal C., Picart C., Ionescu C. Dietary administration of glycine complexed trace minerals can improve performance and slaughter yield in broilers and reduces mineral excretion. Animal Feed Science and Technology, 2017, 232: 182-189 (doi: 10.1016/j.anifeedsci.2017.08.016).

17. Canaj A.B., Kakaroni F.E., Collet A., Milios C.J. $\alpha$-Amino acids: natural and artificial building blocks for discrete polymetallic clusters. Polyhedron, 2018, 151: 1-32 (doi: 10.1016/j.poly.2018.05.005).

18. Yu X., Chau M.C., Tang W.K., Siu C.K., Yao Z.P. Self-assembled binuclear Cu(II)-histidine complex for absolute configuration and enantiomeric excess determination of naproxen by tandem mass spectrometry. Analytical Chemistry, 2018, 90(6): 4089-4097 (doi: 10.1021/acs.analchem.7b05407).

19. Sajadi S.A.A. Metal ion-binding properties of the L-aspartic acid and tartaric acid, a coparative investigation. How can be increased the dosage of mineral absorption in the body. Advances in Bioscience and Biotechnology, 2010, 1(4): 354-360 (doi: 10.4236/abb.2010.14047).

20. Boles G.C., Hightower R.L., Coates R.A., McNary C.P., Berden G., Oomens J., Armentrout P.B. Experimental and theoretical investigations of infrared multiple photon dissociation spectra of aspartic acid complexes with $\mathrm{Zn}^{2+}$ and $\mathrm{Cd}^{2+}$. The Journal of Physical Chemistry B, 2018, 122(14): 3836-3853 (doi: 10.1021/acs.jpcb.8b00801).

21. Murphy J.M., Gaertner A.A., Williams T., McMillen C.D., Powell B.A., Brumaghim J.L. Stability constant determination of sulfur and selenium amino acids with $\mathrm{Cu}(\mathrm{II})$ and $\mathrm{Fe}(\mathrm{II})$. Journal of Inorganic Biochemistry, 2019, 195: 20-30 (doi: 10.1016/j.jinorgbio.2019.03.001).

22. Künzle M., Eckert T., Beck T. Metal-assisted assembly of protein containers loaded with inorganic nanoparticles. Inorganic Chemistry, 2018, 57(21): 13431-13436 (doi: 10.1021/acs.inorgchem.8b01995).

23. Hamley I.W. Protein assemblies: nature-inspired and designed nanostructures. Biomacromolecules, 2019, 20(5): 1829-1848 (doi: 10.1021/acs.biomac.9b00228).

24. Garg M., Sharma N., Sharma S., Kapoor P., Kumar A., Chunduri V., Arora P. Biofortified crops generated by breeding, agronomy, and transgenic approaches are improving lives of millions of people around the world. Frontiers in Nutrition, 2018, 5: 12 (doi: 10.3389/fnut.2018.00012).

25. Biswal B.K., El Sadany M., Kumari D., Sagar P., Singhal N.K., Sharma S., Stobdan T., Shanmugam V. Twin function of zein-zinc coordination complex: wheat nutrient enrichment and nanoshield against pathogenic infection. ACS Sustainable Chemistry \& Engineering, 2018, 6(5): 5877-5887 (doi: 10.1021/acssuschemeng.7b04174).

26. Ohata J., Martin S.C., Ball Z.T. Metal-mediated functionalization of natural peptides and proteins: panning for bioconjugation gold. Angewandte Chemie International Edition, 2019, 58(19): 6176-6199 (doi: 10.1002/anie.201807536). 
27. Цивилева О.М., Перфильева А.И., Иванова А.А., Павлова А.Г. Биополимерные композиты грибного происхождения против бактериального фитопатогена. Биомика, 2018, 10(2): 210-213 (doi: 10.31301/2221-6197.bmcs.2018-30).

28. Воронин С.П., Голубов И.И., Гуменюк А.П., Синолицкий М.К. Биодоступная форма микроэлементных добавок в кормовые смеси для животных и птиц. Пат. 2411747 (РФ). Заявл. 25.12.2008. Опубл. 20.02.2011. Бюл. № 5.

29. Stamets P. Growing gourmet and medicinal mushrooms. Berkeley, 1993.

30. Amelin V.G., Korotkov A.I., Volkova N.M. High-resolution time-of-flight mass spectrometry combined with high-performance liquid chromatography for detection and determination of quinolones and sulfonamides in foods. Journal of Analytical Chemistry, 2015, 70(14): 1629-1634 (doi: 10.1134/S1061934815140026).

31. Амелин В.Г., Андоралов А.М., Волкова Н.М., Коротков А.И., Никешина Т.Б., Сидоров И.И., Тимофеев А.А. Идентификация и определение токсикантов с использованием стандартной добавки в пищевых продуктах, продовольственном сырье и кормах методом высокоэффективной жидкостной хроматографии/времяпролетной масс-спектрометрии высокого разрешения. Аналитика и контроль, 2015, 19(2): 189-207 (doi: 10.15826/analitika.2015.19.2.010).

32. Hansda A., Kumar V., Anshumali. A comparative review towards potential of microbial cells for heavy metal removal with emphasis on biosorption and bioaccumulation. World Journal of Microbiology and Biotechnology, 2016, 32(10): 170 (doi: 10.1007/s11274-016-2117-1).

33. Javanbakht V., Alavi S.A., Zilouei H. Mechanisms of heavy metal removal using microorganisms as biosorbent. Water Science and Technology, 2014, 69(9): 1775-1787 (doi: 10.2166/wst.2013.718).

34. Rabinovich M., Figlas D., Delmastro S., Curvetto N. Copper-and zinc-enriched mycelium of Agaricus blazei Murrill: bioaccumulation and bioavailability. Journal of Medicinal Food, 2007, 10(1): 175-183 (doi: 10.1089/jmf.2005.064).

35. Kachlishvili E., Asatiani M.D., Kobakhidze A., Elisashvili V. Evaluation of lignin-modifying enzyme activity of Trametes spp. (Agaricomycetes) isolated from Georgian forests with an emphasis on T. multicolor biosynthetic potential. International Journal of Medicinal Mushrooms, 2018, 20(10): 971-987 (doi: 10.1615/IntJMedMushrooms.2018028186).

36. Lin T.Y., Tseng A.J., Chao C.H., Lu M.K. Microelements induce changes in characterization of sulfated polysaccharides from Antrodia cinnamomea. International Journal of Biological Macromolecules, 2018, 120(A): 952-958 (doi: 10.1016/j.ijbiomac.2018.08.112).

37. Majesty D., Ijeoma E., Winner K., Prince O. Nutritional, anti-nutritional and biochemical studies on the oyster mushroom, Pleurotus ostreatus. EC Nutrition, 2019, 14(1): 36-59.

38. Mutukwa I.B., Hall III C.A., Cihacek L., Lee C.W. Evaluation of drying method and pretreatment effects on the nutritional and antioxidant properties of oyster mushroom (Pleurotus ostreatus). Journal of Food Processing and Preservation, 2019, 43(4): e13910 (doi: 10.1111/jfpp.13910).

39. Nam W.L., Phang X.Y., Su M.H., Liew R.K., Ma N.L., Rosli M.H.N.B., Lam S.S. Production of bio-fertilizer from microwave vacuum pyrolysis of palm kernel shell for cultivation of Oyster mushroom (Pleurotus ostreatus). Science of The Total Environment, 2018, 624: 9-16 (doi: 10.1016/j.scitotenv.2017.12.108).

40. Phan C.W., Wang J.K., Tan E.Y.Y., Tan Y.S., Sathiya Seelan J.S., Cheah S.C., Vikineswary S. Giant oyster mushroom, Pleurotus giganteus (Agaricomycetes): current status of the cultivation methods, chemical composition, biological, and health-promoting properties. Food Reviews International, 2019, 35(4): 324-341 (doi: 10.1080/87559129.2018.1542710).

41. Sangeetha K., Senthilkumar G., Panneerselvam A., Sathammaipriya N. Cultivation of oyster mushroom (Pleurotus sp.) using different substrates and evaluate their potentials of antibacterial and phytochemicals. International Journal of Research in Pharmaceutical Sciences, 2019, 10(2), 997-1001 (doi: 10.26452/ijrps.v10i2.371).

42. Vetvicka V., Gover O., Karpovsky M., Hayby H., Danay O., Ezov N., Hadar Y., Schwartz B. Immune-modulating activities of glucans extracted from Pleurotus ostreatus and Pleurotus eryngii. Journal of Functional Foods, 2019, 54: 81-91 (doi: 10.1016/j.jff.2018.12.034).

43. Zhu B., Li Y., Hu T., Zhang Y. The hepatoprotective effect of polysaccharides from Pleurotus ostreatus on carbon tetrachloride-induced acute liver injury rats. International Journal of Biological Macromolecules, 2019, 131: 1-9 (doi: 10.1016/j.ijbiomac.2019.03.043).

44. Pozdnyakova N., Dubrovskaya E., Chernyshova M., Makarov O., Golubev S., Balandina S., Turkovskaya $\mathrm{O}$. The degradation of three-ringed polycyclic aromatic hydrocarbons by woodinhabiting fungus Pleurotus ostreatus and soil-inhabiting fungus Agaricus bisporus. Fungal Biology, 2018, 122(5): 363-372 (doi: 10.1016/j.funbio.2018.02.007).

45. Karthikeyan V., Ragunathan R., Johney J., Kabesh K. Production, optimization and purification of laccase produced by Pleurotus ostreatus MH591763. Research \& Reviews: A Journal of Microbiology and Virology, 2019, 9(1): 56-64.

46. Noman E., Al-Gheethi A., Mohamed R.M.S.R., Talip B.A. Myco-remediation of xenobiotic organic compounds for a sustainable environment: a critical review. Topics in Current Chemistry, 2019, 377(3): 17 (doi: 10.1007/s41061-019-0241-8). 
47. Bamigboye C.O., Oloke J.K., Burton M., Dames J.F., Lateef A. Optimization of the process for producing biomass and exopolysaccharide from the king tuber oyster mushroom, Pleurotus tuber-regium (Agaricomycetes), for biotechnological applications. International Journal of Medicinal Mushrooms, 2019, 21(4): 311-322 (doi: 10.1615/IntJMedMushrooms.2019030357).

48. Zhang W.R., Liu S.R., Kuang Y.B., Zheng S.Z. Development of a novel spawn (block spawn) of an edible mushroom, Pleurotus ostreatus, in liquid culture and its cultivation evaluation. Mycobiology, 2019, 47(1): 97-104 (doi: 10.1080/12298093.2018.1552648).

49. Stajić M., Vukojević J., Knežević A., Milovanović I. Influence of trace elements on ligninolytic enzyme activity of Pleurotus ostreatus and P. pulmonarius. BioResources, 2013, 8(2): 3027-3037 (doi: 10.15376/biores.8.2.3027-3037).

50. Baldrian P., Valášková V., Merhautová V., Gabriel J. Degradation of lignocellulose by Pleurotus ostreatus in the presence of copper, manganese, lead and zinc. Research in Microbiology, 2005, 156(5-6): 670-676 (doi: 10.1016/j.resmic.2005.03.007).

51. Yan H., Chang H. Antioxidant and antitumor activities of selenium-and zinc-enriched oyster mushroom in mice. Biological Trace Element Research, 2012, 150(1-3): 236-241 (doi: 10.1007/s12011012-9454-1).

52. Ma X.K., Zhang H., Fam H. Influence of rutin, FeSO4, Tween 80, aspartate and complex vitamins on synthesis of fungal exopolysaccharide. Carbohydrate Polymers, 2013, 92(2): 1188-1196 (doi: 10.1016/j.carbpol.2012.10.027).

53. Glukhova L.B., Frank Y.A., Danilova E.V., Avakyan M.R., Banks D., Tuovinen O.H., Karnachuk O.V. Isolation, characterization, and metal response of novel, acid-tolerant Penicillium spp. from extremely metal-rich waters at a mining site in Transbaikal (Siberia, Russia). Microbial Ecology, 2018, 76(4): 911-924 (doi: 10.1007/s00248-018-1186-0).

54. Ramesh G., Podila G.K., Gay G., Marmeisse R., Reddy M.S. Different patterns of regulation for the copper and cadmium metallothioneins of the ectomycorrhizal fungus Hebeloma cylindrosporum. Applied and Environmental Microbiology, 2009, 75(8): 2266-2274 (doi: 10.1128/AEM.02142-08).

55. Панкратов А.Н., Цивилева О.М., Цымбал О.А., Юрасов Н.А. Каналы фрагментации молекулярных ионов ГХ-МС-регистрируемых компонентов сред глубинного культивирования базидиомицета шиитаке в присутствии диацетофенонилселенида. Изомеризация дигидрофуранов и их катион-радикалов. Известия Саратовского университета. Новая серия. Серия: Химия. Биология. Экология, 2015, 15(3): 16-25 (doi: 10.18500/1816-9775-2015-15-3-16-25).

56. Tsivileva O.M., Pankratov A.N., Misin V.M., Zavyalov A.Yu., Volkov V.A., Tsymbal O.A., Yurasov N.A., Nikitina V.E. Antioxidant properties of the Artist's Conk medicinal mushroom, Ganoderma applanatum (Agaricomycetes), upon cultivation with para-substituted phenolic compounds and tea leaf extracts. International Journal of Medicinal Mushrooms, 2018, 20(6): 549-560 (doi: 10.1615/IntJMedMushrooms.2018026329).

57. Древко Б.И., Древко Р.И., Антипов В.А., Чернуха Б.А., Яковлев А.Н. Средство для лечения и профилактики инфекционных заболеваний и отравлений животных и птии, повышающее их продуктивность и сохранность. Пат. 2171110 (РФ) МПК 7 А $61 \mathrm{~K} \mathrm{33/04.} \mathrm{Заявл.}$ 26.05.1999. Опубл. 27.07.2001. Бюл. № 21.

58. Шарофова М.У., Сагдиева Ш.С., Абдуллаев С.Ф., Маслов В.А., Рахими Ф., Миршахи М. K вопросу о содержании переходных элементов в структурах растений. Доклады Академии наук Республики Таджикистан, 2018, 61(4): 350-359.

59. Khokhlova E.A., Kachala V.V., Ananikov V.P. Conversion of carbohydrates to 5-hydroxymethylfurfural: the nature of the observed selectivity decrease and microwave radiation effect. Russian Chemical Bulletin, 2013, 62(3): 830-835 (doi: 10.1007/s11172-013-0112-3).

60. Sharma V.K., Choi J., Sharma N., Choi M., Seo S.-Y. In vitro anti-tyrosinase activity of 5(hydroxymethyl)-2-furfural isolated from Dictyophora indusiata. Phytotherapy Research, 2004, 18(10): 841-844 (doi: 10.1002/ptr.1428).

61. Kim Y.M., Yun J., Lee C.-K., Lee H., Min K.R., Kim Y. Oxyresveratrol and hydroxystilbene compounds inhibitory effect on tyrosinase and mechanism of action. Journal of Biological Chemistry, 2002, 277(18): 16340-16344 (doi: 10.1074/jbc.M200678200).

62. Razak D.L.A., Fadzil N.H.M., Jamaluddin A., Rashid N.Y.A., Sani N.A., Manan M.A. Effects of different extracting conditions on anti-tyrosinase and antioxidant activities of Schizophyllum commune fruit bodies. Biocatalysis and Agricultural Biotechnology, 2019, 19: 101116 (doi: 10.1016/j.bcab.2019.101116).

63. Çayan F., Tel G., Duru M.E., Öztürk M., Türkoğlu A., Harmandar M. Application of GC, GC-MSD, ICP-MS and spectrophotometric methods for the determination of chemical composition and in vitro bioactivities of Chroogomphus rutilus: the edible mushroom species. Food Analytical Methods, 2014, 7(2): 449-458 (doi: 10.1007/s12161-013-9644-2).

64. Tel G., Deveci E., Küçükaydın S., Özler M.A., Duru M.E., Harmandar M. Evaluation of antioxidant activity of Armillaria tabescens, Leucopaxillus gentianeus and Suillus granulatus: the mushroom species from Anatolia. Eurasian Journal of Analytical Chemistry, 2013, 8(3): 136-147.

65. Chen J.-T., Su H.-J., Huang J.-W. Isolation and identification of secondary metabolites of Clitocybe nuda responsible for inhibition of zoospore germination of Phytophthora capsici. Journal of Agricultural and Food Chemistry, 2012, 60(30): 7341-7344 (doi: 10.1021/jf301570y). 
66. Cheung L.M., Cheung P.C.K., Ooi V.E.C. Antioxidant activity and total phenolics of edible mushroom extracts. Food Chemistry, 2003, 81(2): 249-255 (doi: 10.1016/S0308-8146(02)00419-3).

67. Karpukhina G.V., Emanuel N.M. Classification of synergistic mixtures of antioxidants and synergism mechanisms. Doklady Akademii Nauk SSSR, 1984, 276(5): 1163-1167.

68. Burlakova E.B., Mazaletskaya L.I., Sheludchenko N.I., Shishkina L.N. Inhibitory effect of the mixtures of phenol antioxidants and phosphatidylcholine. Russian Chemical Bulletin, 1995, 44(6): 1014-1020 (doi: 10.1007/BF00707045).

69. Mazaletskaya L.I., Sheludchenko N.I., Shishkina L.N. Role of the nitrogen-containing moiety of phosphatidylcholines in the mechanism of inhibiting action of their mixtures with natural and synthetic antioxidants. Petroleum Chemistry, 2008, 48(2): 105-111 (doi: 10.1134/S0965544108020059).

70. Lanfranco L., Novero M., Bonfante P. The mycorrhizal fungus Gigaspora margarita possesses a $\mathrm{CuZn}$ superoxide dismutase that is up-regulated during symbiosis with legume hosts. Plant Physiology, 2005, 137(4): 1319-1330 (doi: 10.1104/pp.104.050435).

71. Sharma S.S., Dietz K.J. The significance of amino acids and amino acid-derived molecules in plant responses and adaptation to heavy metal stress. Journal of Experimental Botany, 2006, 57(4): 711-726 (doi: 10.1093/jxb/erj073).

72. Aguilar F. Manganese ascorbate, manganese aspartate, manganese bisglycinate and manganese pidolate as sources of manganese added for nutritional purposes to food supplements. European Food Safety Authority Journal, 2009, 7(6): 1114.

73. Mohamed E.T., Said A.I., El-Sayed S.A. Protective effect of zinc aspartate against acetaminophen induced hepato-renal toxicity in albino rats. Journal of Radiation Research and Applied Sciences, 2011, 4(2(B)): 709-723.

74. Le Prell C.G., Ojano-Dirain C., Rudnick E.W., Nelson M.A., DeRemer S.J., Prieskorn D.M., Miller J.M. Assessment of nutrient supplement to reduce gentamicin-induced ototoxicity. Journal of the Association for Research in Otolaryngology, 2014, 15(3): 375-393 (doi: 10.1007/s10162014-0448-x).

75. Afanas'ev I.B., Suslova T.B., Cheremisina Z.P., Abramova N.E., Korkina L.G. Study of antioxidant properties of metal aspartates. Analyst, 1995, 120(3): 859-862 (doi: 10.1039/AN9952000859).

76. Özkan K.U., Boran C., Kilinc M., Garipardic M., Kuruta E.B. The effect of zinc aspartate pretreatment on ischemia-reperfusion injury and early changes of blood and tissue antioxidant enzyme activities after unilateral testicular torsion-detorsion. Journal of Pediatric Surgery, 2004, 39(1): 91-95 (doi: 10.1016/j.jpedsurg.2003.09.013).

77. Турковская О.В., Дубровская Е.В., Гринев В.С., Баландина С.А., Позднякова Н.Н. Деструктивная активность и продукция внеклеточных пероксидаз у микромицетов с различной экологической стратегией. Сельскохозяйственная биология, 2019, 54(1): 65-75 (doi: 10.15389/agrobiology.2019.1.65rus).

\author{
1ФГБУН Институт биохимии и физиологии растений \\ и микроорганизмов РАН, \\ 410049 Россия, г. Саратов, пр. Энтузиастов, 13, \\ e-mail: tsivileva@ibppm.ru $\bowtie$, andrejsh93@gmail.com,vvf2593@gmail.com, \\ lyubun@ibppm.ru, nikitina_v@ibppm.ru; \\ 2ФГБОУ ВО Владимирский государственный университет \\ им. Александра Григорьевича \\ и Николая Григорьевича Столетовых, \\ 600000 Россия, г. Владимир, ул. Горького, 87, \\ e-mail: amelinvg@mail.ru; \\ 3 АO «Биоамид», \\ 410033 Россия, г. Саратов, ул. Международная, 27 \\ e-mail: bioamid@yandex.ru
}

Поступила в редакцию

21 октября 2019 года

Sel’skokhozyaistvennaya biologiya [Agricultural Biology], 2020, V. 55, № 3, pp. 606-627

\title{
HOW THE BASIDIOMYCETES RESPOND TO BIOGENIC ASPARTATE- BOUND METALS(II) OF VARIABLE VALENCY IN GROWTH MEDIA
}

\author{
O.M. Tsivileva ${ }^{1}$, A.N. Shaternikov', V.V. Fadeev', E.V. Lyubun ${ }^{1}$, V.G. Amelin' ${ }^{2}$, \\ S.P. Voronin ${ }^{3}$, A.P. Gumenyuk ${ }^{3}$, V.E. Nikitina ${ }^{1}$
}

${ }^{1}$ Institute of Biochemistry and Physiology of Plants and Microorganisms RAS, 13, pr. Entuziastov, Saratov, 410049 Russia, e-mail tsivileva@ibppm.ru ( $₫$ corresponding author), andrejsh93@gmail.com, vvf2593@gmail.com, lyubun@ibppm.ru, nikitina_v@ibppm.ru;

${ }^{2}$ Alexander and Nilkolay Stoletovs Vladimir State University, 87, ul. Gor'kogo, Vladimir, 600000 Russia, e-mail amelinvg@mail.ru;

3AO «Bioamid» 27, ul. Mezhdunarozhnaya, Saratov, 410033 Russia, e-mail bioamid@yandex.ru 
ORCID:

Tsivileva O.M. orcid.org/0000-0002-5269-349X

Fadeev V.V. orcid.org/0000-0002-9725-3439

Amelin V.G. orcid.org/0000-0001-7477-7398

Gumenyuk A.P. orcid.org/0000-0002-1147-088X

The authors declare no conflict of interests

Acknowledgements:

The authors express gratitude to Prof. A.N. Pankratov (Institute of Chemistry, Chernyshevskii Saratov State National Research University) for research-organizing efforts.

Received October 21, 2019
Shaternikov A.N. orcid.org/0000-0002-1364-1902

Lyubun E.V. orcid.org/0000-0002-8814-6949

Voronin S.P. orcid.org/0000-0002-3530-1001

Nikitina V.E. orcid.org/0000-0003-2687-7890

\section{Abstract}

Current studies on artificial mushroom cultivation are aimed at optimizing mineral nutrition and the delivery of metals(II). Organically bound trace metals are superior to their inorganic precursors. $\mathrm{Cu}, \mathrm{Mn}, \mathrm{Fe}, \mathrm{Zn}$, and $\mathrm{Co}$ metal(II) complexation with essential amino acids seems to be a solution to the bioavailability problem, thus making amino acid chelates of biogenic metals relevant for study. In particular, aspartic acid salts potentially could improve cultivable mushroom growing due to use of bioavailable organic compounds of microelements. However, a comprehensive study on mineral nutrition of cultivated mushrooms using biogenic metal chelates has not been conducted previously. This paper is the first to discover and characterize the effect of metal(II) aspartates on growth, biochemical response, antibacterial activity of mycelium submerged cultures, and fruitingbody formation in basidiomycetes Ganoderma lucidum strain 1315, Grifola umbellate strain 1622, Laetiporus sulphureus strain 120707, Lentinula edodes strain F-249, and Pleurotus ostreatus strains 69, BK1702 and HK352. The work was aimed at elucidating and comparing action of the variable-valent metal(II) aspartates on the physiological and biochemical parameters of the basidiomycetes. Glucose- and wheat powder-based nutrient media supplemented with $1 \times 10^{-4} \mathrm{~mol} / \mathrm{l} \mathrm{Cu}(\mathrm{II}), \mathrm{Mn}(\mathrm{II})$, $\mathrm{Fe}(\mathrm{II}), \mathrm{Zn}(\mathrm{II})$, and $\mathrm{Co}(\mathrm{II})$ aspartates were used to grow mycelia in submerged culture, comparing growth parameters and production of fruiting bodies. Media without any supplements or with $2 \times 10^{-4} \mathrm{~mol} / \mathrm{l} \mathrm{L}$-aspartic acid were control. Antimicrobial activity of the metal-containing biosamples against phytopathogenic bacteria Micrococcus luteus B-109, Pectobacterium carotovorum subsp. carotovorum (strains 603 and MI), Pectobacterium atrosepticum 1043, Pseudomonas fluorescens EL-2.1, Xanthomonas campestris B-610 was determined by agar well diffusion method. A pool of secondary metabolites was analyzed by high performance liquid chromatography/high resolution time-of-flight mass-spectrometry method. Metal levels in specimens were quantified by atomic absorption spectroscopy technique. The fruiting body formation was tested in the lab and upon commercial growing. In lab tests, it was established that amino acid chelates of biogenic metals(II) intensify mycelium growth in liquid-submerged culture and fruiting body formation. Chelates of copper, manganese, zinc, and to a lesser extent iron, exhibited the significant growth-promoting effect on the basidiomycetes' mycelium under the submerged culture conditions, especially in respect to lacquered polypore, umbrella polypore, and sulfur-yellow polypore. The additives of $\mathrm{Cu}(\mathrm{Asp}) 2, \mathrm{Mn}(\mathrm{Asp}) 2, \mathrm{Zn}(\mathrm{Asp}) 2$ showed only slight stimulation or even inhibition of $P$. ostreatus 69 growth. Aspartic acid caused a suppressing impact on mycelia accumulation, regardless of the basidiomycetes' taxonomic characteristics. At the oyster mushroom fermentation in the presence of biogenic metal aspartates, the interstrain distinctions occurred among rapidly and slower growing cultures in relation to the metal chelates' exogenic action. Thus, in assays with $\mathrm{Cu}(\mathrm{Asp}) 2$ and $\mathrm{Zn}(\mathrm{Asp}) 2$, the strain $P$. ostreatus BK1702 had an advantage over others in accumulating biomass. Manganese chelate exerted the most profound positive effect on the fast-growing strain $P$. ostreatus HK352. The latter, however, was suppressed in its development to the greatest extent compared with BK1702 or 69, when the cobalt organic salt appeared in the liquid medium. Earlier we discussed in detail the items related to these substances' increased level resulted from the exogenic action of some compounds. As a biochemical response of cultures to the above aspartates occurrence in the starting nutrient media, the organic substances with double bond, which were not detected in the absence of the same additives, appeared in the growth liquid. These substances were aromatic alcohol 2-phenylethanol, as well as parahydroxyphenylacetic acid, the latter's maximal extracellular concentration evaluated by the analytical signal being observed at $\mathrm{Mn}(\mathrm{Asp}) 2$ introduction. According to the data we gathered by physicochemical research, the metal(II) aspartates, notably $\mathrm{Mn}(\mathrm{Asp}) 2, \mathrm{Cu}(\mathrm{Asp}) 2$ in the growth liquid induced the increased level of 5-hydroxymethyl-2-furaldehyde, dihydropyrone (structurally similar to kojic acid), para-hydroxyphenylacetic acid, which antioxidative properties are important for mushroom culture. Positive impact of the certain combinations of $\mathrm{Mn}(\mathrm{II}), \mathrm{Cu}(\mathrm{II}), \mathrm{Fe}(\mathrm{II}), \mathrm{Zn}$ (II) chelate compounds on $P$. ostreatus vital functions could be efficiently used for elaborating upon scientific foundations and developing the technology of mushroom mineral nutrition, including wide-scale growing. Biogenic metal aspartates could serve as the active ingredient in biopreparations for commercial mushroom culture. Oyster mushroom fruit bodies and mycelium parameters provided by the aspartates implementation allowed us to propose manganese(II) chelate for put into practice.

Keywords: basidiomycetes, physiological and biochemical features, biometals, amino acid chelates, aspartates. 